\title{
A Modelling Approach for Assessing the Hydrogeological Equilibrium of the Karst, Coastal Aquifer of the Salento Peninsula (Southeastern Italy): Evaluating the Effects of a MAR Facility for Wastewater Reuse
}

\author{
Giovanna De Filippis $\mathbb{D}^{1},{ }^{1}$ Stefano Margiotta, ${ }^{2}$ Claudia Branca, ${ }^{2}$ and Sergio Luigi Negri ${ }^{2}$ \\ ${ }^{1}$ Institute of Life Sciences, Scuola Superiore Sant'Anna, Pisa, Italy \\ ${ }^{2}$ DiSTeBA, Università del Salento, Lecce, Italy \\ Correspondence should be addressed to Giovanna De Filippis; g.defilippis@santannapisa.it
}

Received 15 November 2018; Revised 15 January 2019; Accepted 10 February 2019; Published 14 May 2019

Guest Editor: Giovanni Mongelli

Copyright (C) 2019 Giovanna De Filippis et al. This is an open access article distributed under the Creative Commons Attribution License, which permits unrestricted use, distribution, and reproduction in any medium, provided the original work is properly cited.

\begin{abstract}
The Salento Peninsula is characterized by poor surface water resources, due to the karstic nature of its territory. On the other hand, important groundwater resources are located in the deep, karst, coastal aquifer, which is of strategic importance for the economic and social development of the area. The increasing water demand, however, if not properly managed may pose serious problems to the hydrogeological equilibrium of this aquifer, which is highly susceptible to natural and anthropogenic changes and to saltwater intrusion. Taking steps from the previous works, the present paper focuses on the characterization of the deep aquifer of the Adriatic portion of the Salento Peninsula from a quantitative point of view by means of modelling tools for the simulation of groundwater dynamics. Conclusions about the extent of the saltwater intrusion phenomenon are consequently inferred. As a result of the implementation of a density-dependent flow model, the lateral extent of such phenomenon and the vertical depth of the transition zone between freshwater and saltwater were inferred, highlighting also the role of major faults which characterize the hydraulic behaviour of the karst system under exam. The model was also applied to design a Managed Aquifer Recharge facility for management and protection of the hydrogeological equilibrium of the deep aquifer. Its positive effects on the advancement of the saline front were highlighted. Model results also allowed identifying areas where the lack of data prevents a proper comprehension of the hydrogeological processes investigated, thus representing a supporting tool for planning further monitoring campaigns.
\end{abstract}

\section{Introduction}

Coastal aquifers are major sources of freshwater in arid and semiarid areas of the Mediterranean basin, which face large precipitation variability, frequent drought episodes, high evapotranspiration rates, and increasing population growth [1-3]. Also, karst landforms are pretty widespread in Mediterranean areas [4]. As karst regions often are characterized by scarce surface water supply, costal, karst aquifers contribute to a large part of the water supply in many European countries because of their high storage capacity and permeability [5]. Due to anthropogenic increasing exploitation of groundwater resources and as a direct impact of climate change, coastal areas in the Mediterranean region are facing alarming water level decline and severe water quality degradation due to saltwater intrusion. This in turn affects human health, socioeconomic development, and ecosystem service sustainability [6-8].

The effects of climate change and human stresses on groundwater salinization and quantity in coastal, karst areas of the Mediterranean region are major concerns and are widely being faced by scientists, water decision-makers, and politicians $[4,9]$. In view of achieving a sustainable use of groundwater resources, different approaches have been 
adopted to characterize coastal aquifer behaviour and their spatiotemporal evolution in response to different hydrologic and anthropogenic stresses [3, 7]. Among these approaches, geochemical methods based on measures of electrical conductivity, chloride concentration, and other cation and anion concentrations have been used to detect seawater contamination [10, 11]. Eissa et al. [12] pointed out the use of groundwater chemistry and stable isotopes to evaluate seawater intrusion in a coastal Egyptian area. Hammami Abidi et al. [13] deal with the combination of hydrogeochemical, isotopic, statistical, and GIS approaches to infer controlling factors on groundwater composition in northeastern Tunisia. Also, a great attention is being focused on remote sensing [14] and geophysical methods for subsurface exploration, which can contribute to coastal environment characterization $[12,15-17]$. The scientific literature is also rich in examples of numerical models, which are evaluated as efficient tools to test a wide range of assumptions and to predict groundwater body evolution under different scenarios of hydrologic and anthropogenic stresses [18]. Also, the European and national regulations on coastal aquifer management foster the use of modelling tools to assess the quantitative status of these natural systems and to predict the evolution of the saltwater intrusion phenomenon and their hydrogeological equilibrium as a result of overexploitation and climate change. All the studies mentioned above emphasize the importance of monitoring groundwater salinization and quantity to assure a sustainable and safe use of this resource.

Monitoring groundwater salinization and quantity and the abovementioned approaches may support policy makers to design management strategies. Among these, Managed Aquifer Recharge (MAR) schemes are being taken into consideration to protect stressed groundwater systems, by enhancing the underground water storage capacity, and to improve groundwater quality [19]. In coastal aquifers, improvement of water volumes by means of MAR techniques results in reduction and prevention of seawater intrusion [20]. Examples of MAR application to manage coastal aquifers may be found in Bonilla Valverde et al. [21], Kazakis et al. [22, 23], and Tzoraki et al. [24].

Due to its karstic nature, the Salento Peninsula is characterized by scarce availability of surface water resources. On the other hand, important volumes of groundwater are hosted in the deep, karst aquifer, which represents a strategic resource for the socioeconomic aspects of this Mediterranean region [25]. Such aquifer, indeed, is the main source of freshwater in the region able to satisfy the increasingly widespread demand related to productive activities [26]. Regione Puglia \& Autorità di Bacino della Puglia [27] estimate that an average volume of about $358 \mathrm{Mm}^{3}$ of freshwater is pumped yearly from the deep aquifer of the Salento Peninsula. 69\% of this volume is intended to agriculture activities, while $25 \%$ meets drinking water needs, and the remaining $6 \%$ is addressed to the industrial sector.

Anyway, the karstic nature of the deep aquifer of the Salento Peninsula poses serious management problems, as it is highly susceptible to overexploitation and it is characterized by low recharge rates, due to scarce precipitation rates, high evapotranspiration rates, and lack of surface water bodies [28]. Anthropogenic stresses are further exacerbated by tourism activities during the summer season. In this framework, an alarming imbalance between freshwater demand and groundwater availability and a high vulnerability to saltwater intrusion have been detected in the last decades either by monitoring [29, 30] and modelling $[28,31-36]$. This represents a major concern in this coastal ecosystem, as salinization may cause negative impacts on irrigated crops, soil fertility [37], and the socioeconomic development of the region.

Climate change and the non-sustainable use of groundwater resources in this area contribute to the deterioration of the quantitative status of the deep, karst aquifer and exacerbate the saltwater intrusion phenomenon. As such, defining sustainable management strategies is of paramount importance to counteract the negative trend of these issues. To this aim, adopting numerical modelling techniques may represent a valuable methodology to assess the occurrence of saltwater intrusion and to propose solutions to cope with the advancement of this phenomenon.

The deep aquifer of the Salento Peninsula has been the object of some previous modelling studies. The first steadystate numerical model was developed for the deep aquifer over the whole Salento Peninsula by Giudici et al. [28]. The aim of that analysis was to evaluate how the complex hydrostratigraphic architecture and the hydrogeological conditions of the region affect the hydrodynamics of such aquifer and its balance. In that paper, the areas potentially affected by saltwater intrusion were inferred adopting a sharp-interface approach. The conceptual model reported in Giudici et al. [28] was then enhanced by De Filippis et al. [32], focusing on an in-depth investigation of the hydrostratigraphic setup in areas where the deep aquifer was found to be saturated with saltwater. Furthermore, a sensitivity analysis was performed to identify the most sensitive parameters in the numerical model. Two scenarios were consequently developed to quantify the piezometric head changes in case of rainfall decrease and abstraction increase. In both cases, the model predicted a lowering of the piezometric head in the central part of the peninsula. Areas affected by saltwater intrusion were calculated accordingly, using the same approach adopted by Giudici et al. [28].

In the following, Romanazzi et al. [36] developed a 3D density-dependent flow model of the southern part of the Salento Peninsula (Lecce province) under transient conditions. In that paper, the authors developed three scenarios: scenario P1 was referred to the period 1930-1979 and was calibrated using piezometric data dating back to 1930s at 11 wells. Results of scenario P1 were used to initialize the piezometric head for scenario P2, referred to the period 1980-1989, and results of scenario P2 were consequently used to initialize the piezometric head for scenario P3, referred to the period 1990-1999. Both scenarios P2 and P3 were validated with piezometric data at 10 wells in the study area. As a result of scenarios $\mathrm{P} 1, \mathrm{P} 2$, and $\mathrm{P} 3$, a decrease of the piezometric head up to $2.5 \mathrm{~m}$ was identified from 30 s to $90 \mathrm{~s}$. They further simulated an increase of salinity values, up to more than $1000 \mathrm{mg} / \mathrm{l}$ between 50 and $100 \mathrm{~m}$ below the mean 
sea level and up to $6 \mathrm{~km}$ inland. The same result was also detected about 10 years before by Margiotta and Negri [38]. The same modelling approach was also adopted to simulate future scenarios, F1 from 2001 to 2020, F2 from 2021 to 2040, and F3 from 2041 to 2060, in order to include predictions of changes in rainfall, temperature, sea level, and seawater salinity. The results show a piezometric decrease of more than $2.5 \mathrm{~m}$ up to 2060 with respect to the steady-state conditions. On the other hand, salinity would increase up to more than $5000 \mathrm{mg} / \mathrm{l}$ in 2060 , especially along the western Ionian coast.

Generally speaking, a full comparison between results obtained by Giudici et al. [28] and De Filippis et al. [32] and those obtained by Romanazzi et al. [36] cannot be performed. As an example, the piezometric trend simulated by Romanazzi et al. [36] is smoother, with a watershed which can be clearly identified in the center of the peninsula. On the other hand, the former results by Giudici et al. [28] and De Filippis et al. [32] identified a critical area near Otranto, where high piezometric levels were detected. This was also reported in the previous studies $[39,40]$, while it is not mentioned at all by Romanazzi et al. [36].

In this paper, a modelling approach taking steps from the analysis reported in De Filippis et al. [32] is presented. It is aimed at characterizing the deep aquifer of the Adriatic portion of the Salento Peninsula by means of modelling tools for the simulation of groundwater dynamics and the saltwater intrusion phenomenon. This was carried out by applying the following finite difference codes: MODFLOW-2005 [41] for the simulation of groundwater flow and SEAWAT [42] for the simulation of density-dependent flow. Both codes were applied through the QGIS-integrated FREEWAT interface [43-45], which allows taking advantage of GIS spatial analysis tools for model implementation and benefiting from several numerical codes (such as MODFLOW, SEAWAT, and other MODFLOW-related codes) for the simulation of a number of hydrological processes.

A major advancement with respect to the previous works consists in modelling the karst aquifer under exam with an equivalent porous medium approach (as already done in the abovementioned papers), but taking also into account the occurrence of structural features typical of karst environments (e.g., main fractures identified at the regional scale).

A management strategy to counteract the advancement of the saline wedge has been proposed as well. This consists in a MAR technique involving a set of injection wells, which use treated wastewater coming from a near wastewater treatment plant.

The methodology presented in this paper allowed identifying still existing gaps in the understanding of the hydrogeological equilibrium of the deep, karst aquifer of the Salento Peninsula and sets the stage for further investigations in this regard.

\section{Geographical and Hydrogeological Setting of the Study Area}

The study area (Figure 1) extends for about $1850 \mathrm{~km}^{2}$. It is bounded by the Adriatic coast on the eastern and southern sides, while the western boundary is represented by a straight line which roughly connects the municipalities of S. Pancrazio S.no and Tiggiano, and the northern one is nearly located along the boundary between Lecce and Brindisi provinces.

The northern boundary identifies a no-flow boundary according to De Filippis et al. [32].

From a geological point of view, the underground of the whole Salento Peninsula is characterized by a complex stratigraphic setup related to geotectonic events and eustatic variations which characterized the geomorphology of the region. The base of such structure is represented by a basement of Cretaceous limestones overlayed by clayey-sandy sediments of Neogene and Pleistocene. As stated in Margiotta and Negri [29], seven lithostratigraphic units can be identified in the Salento Peninsula and in the study area. From the bottom to the top, these units are the following:

(i) The Altamura limestone, made of fractured, karst sediments dating back to Cretaceous and deposited after periodic emergences of the Apulian platform

(ii) The Galatone unit, made of thin layers of compact limestone dating back to Oligocene, overlies Cretaceous limestones with interbedded residual deposits

(iii) The Miocene unit, which includes different lithologies made of calcarenites and marly limestones

(iv) The Pliocene unit, which includes different lithologies made of breccias and calcareous conglomerates. The Miocene and Pliocene units were deposited during a period when the region was submerged by seawater

(v) The Gravina calcarenites, dating back to Lower Pleistocene

(vi) The Subappennine clays, dating back to Middle Pleistocene. These last two units were deposited during a further period of submersion which affected a portion of the peninsula

(vii) The Terrace deposits, made of sands and silty sands deposited after repeated lifting and lowering of the mean sea level

The underground of the Salento Peninsula is characterized by a rather complex hydrodynamics, from the hydrogeological perspective, as the abovementioned units set the framework for a multilayered system, where the main groundwater body is represented by the deep, karst aquifer hosted in the Altamura limestone sediments [28, $36,46,47]$. Such aquifer, indeed, is the widest one and the most exploited for human activities. Over the whole peninsula, this aquifer takes the shape of a lens floating above saltwater, with a maximum thickness in the center of the peninsula. Since this aquifer is characterized by a high degree of permeability, mostly related to the karstic nature of its sediments, the piezometric head stands at heights which range between the mean sea level (at the coastline) and about $4 \mathrm{~m}$ above the mean sea level (msl). Furthermore, the deep 


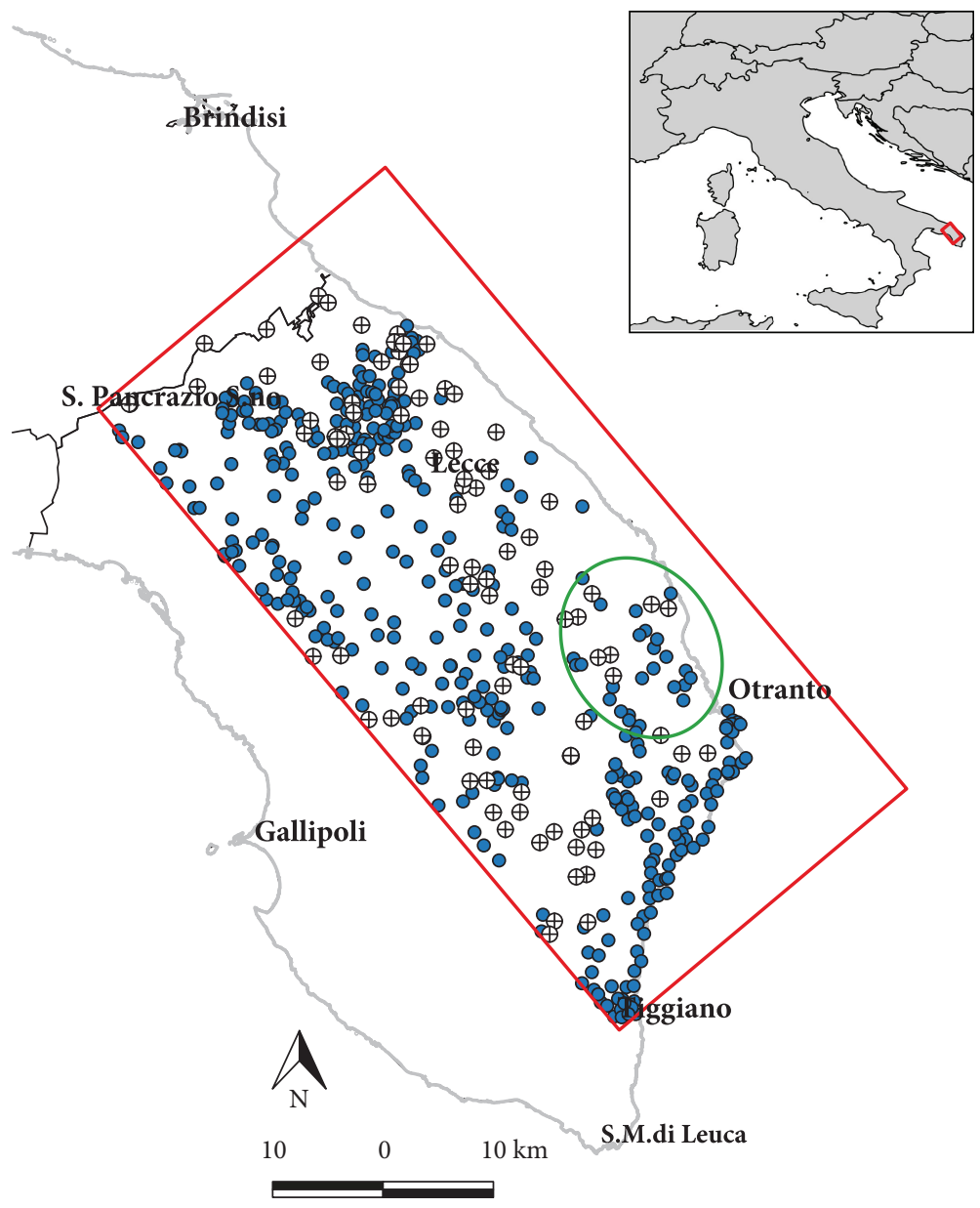

$\oplus \quad$ Wells with piezometric measurements

- Wells with stratigraphic and piezometric information

Boundaries among provinces

FIGURE 1: Location and extent of the study area and location of the wells where lithostratigraphic and piezometric information was available. The green circle indicates an area where the reconstruction of the stratigraphic setup needed specific data processing.

aquifer is mostly phreatic in the central-western part of the region, while the top of the Altamura limestone stands at hundreds of meters below msl in the eastern portion, where the aquifer is mainly confined.

Some local aquifers can be found in the Plio-Pleistocene sediments, mostly located at topographically depressed locations. However, these can be hardly identified, due to the heterogeneous permeability characteristics of the lithotypes which make up these sediments. For this reason, the analysis presented in this paper refers to the deep aquifer only, while the contribution of the overlying units to the vertical component of the hydraulic flow was taken into account while evaluating the rainfall recharge term.

The Galatone unit, residual deposits, and the Subappennine clays are made of poorly permeable sediments. As such, from a hydrogeological point of view, they mainly act as aquitards.

Figure 2 reports a lithological map of the southern part of the Salento Peninsula (Lecce province) and four schematic cross sections of the complex hydrostratigrahic setup. Table 1 reports a list of the lithostratigraphic units identified, along with their lithological and hydrogeological features.

\section{Materials and Methods}

This section reports a thorough discussion about the reconstruction of the stratigraphic setup, the hydrogeological conceptual model, and the setting up of the density-dependent flow model in the study area.

Model results will be discussed in detail in the following section, where a management strategy proposal based on a MAR scheme and insights about the major criticalities identified will be presented as well.

3.1. Reconstruction of the Stratigraphic Setup. The geometry of the underground in the study area was inferred from interpolation of an integrated dataset, consisting of point lithostratigraphic data reported in Margiotta and Negri [29] 


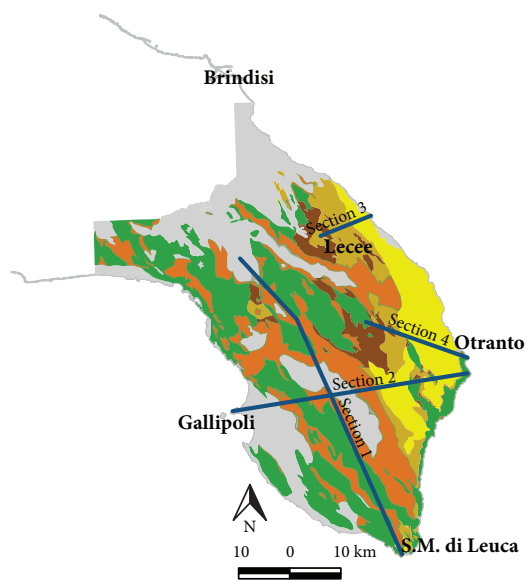

Lithology

Q3: Middle-to-Higher Pleistocene (Terrace deposits)

Q2: Middle Pleistocene (Subappennine clays)

Q1: Lower Pleistocene (Gravina calcarenites)

P: Lower-to-Higher Pliocene (Leuca formation - Uggiano la Chiesa formation - Trubi)

M2: Higher Miocene (Andrano calcarenites)

M1: Lower-to-Higher Miocene (Pietra Leccese)

C: Cretaceous (Altamura limestone)

(a)
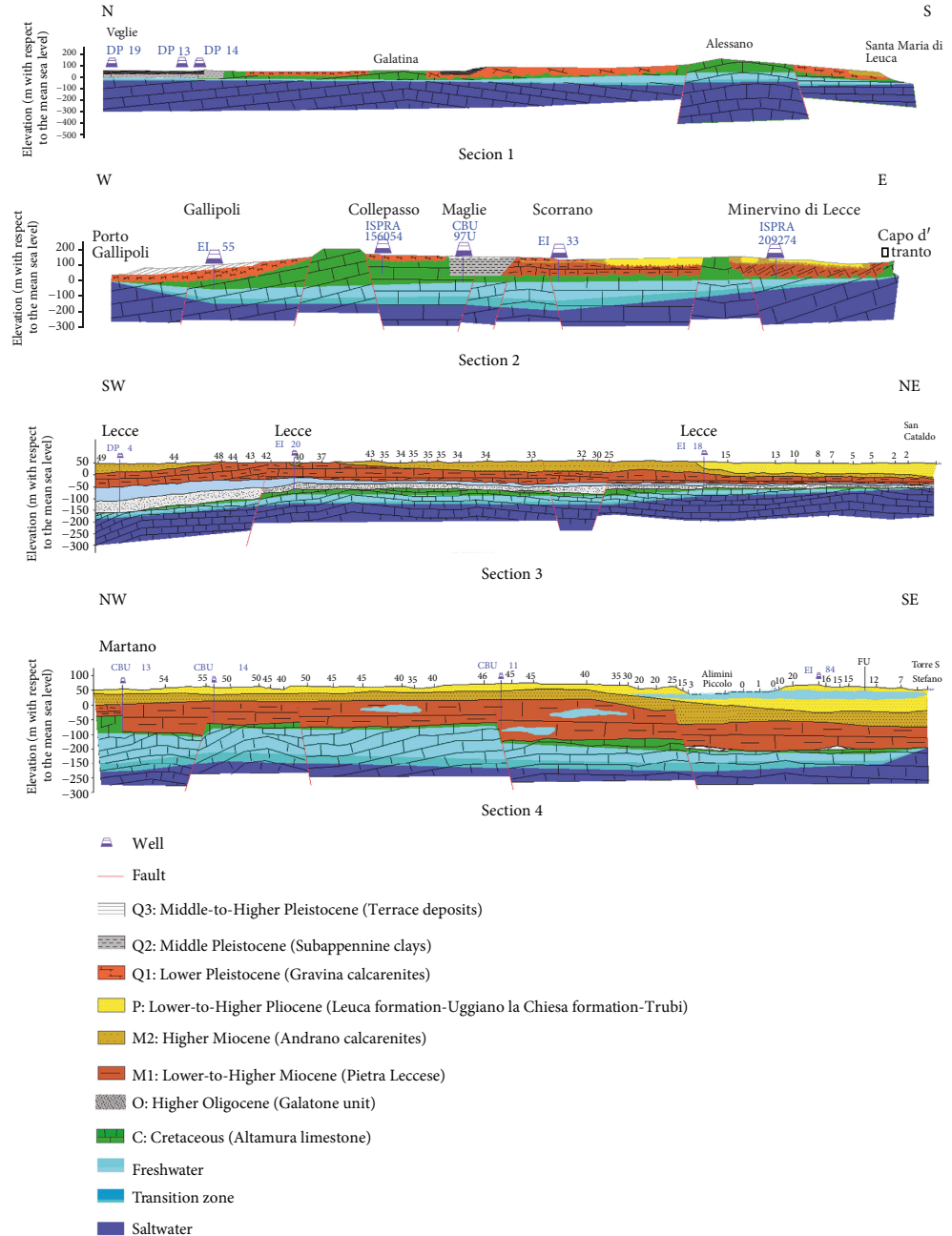

(b)

FIGURE 2: (a) Lithological map of the southern part of the Salento Peninsula. (b) Hydrostratigraphic cross sections along profiles drawn in subfigure (a). Fill colors and legend items are the same in both subfigures. 
TABLE 1: List of the lithostratigraphic units identified and their hydrogeological characteristics (modified after De Filippis et al. [33]).

\begin{tabular}{lccc}
\hline Lithostratigraphic unit & Lithological features & Geological age & Hydrogeological characteristics \\
\hline Altamura limestone & Limestones and dolomitic limestones & Cretaceous & Fractured and karst main aquifer \\
Galatone unit & Compact limestones, marls, and sandy clay & Oligocene & Generally impermeable deposits \\
Miocene unit & Calcarenites and marly limestones & Miocene & Porous aquifers \\
Pliocene unit & Breccias and calcareous conglomerates & Pliocene & Porous aquifers \\
Gravina calcarenites & Biodetritic calcarenite & Lower Pleistocene & Porous aquifers \\
Subappennine clays & Clays & Lower to Middle Pleistocene & Aquitard \\
Terrace deposits & Sands and silty sands & Upper Pleistocene & Porous shallow aquifers \\
\hline
\end{tabular}

and cross sections produced at the Laboratory of Hydrogeophysics and Stratigraphy for Natural Hazards of the University of Salento. The whole dataset is made of 504 points reported in Figure 1. At each point, values of the top elevation of the Altamura limestone and values of the thicknesses of the overlying lithostratigraphic units are available. Such values were processed by interpolation with the kriging method over a grid of square cells $20 \mathrm{~m} \times 20 \mathrm{~m}$ wide.

A critical area (circled area in Figure 1) was highlighted. At this location, indeed, the interpolation of the top elevation of the Altamura limestone resulted in a surface intersecting the thickness of the overlying Galatone unit. To overcome this inconsistency, the top elevation of the Altamura limestone at those points was inferred by subtracting the thicknesses of the overlying units from the elevation of the ground surface.

Figure 3(a) reports the resulting top elevation of the deep aquifer, while Figure 3(b) shows the ratio among the thicknesses of the lithostratigraphic units identified in the study area, along a SW-NE profile. As stated in the section above, two portions can be identified in the study area: (i) the one along the coastline, where the top elevation of the deep aquifer is far below the msl and the aquifer is confined, and (ii) the western portion, where the Altamura limestone locally outcrops and the aquifer is unconfined.

The color map reported in Figure 3(a) allows identifying three important graben structures at least: the one located near Lecce, the one between Cavallino and the area south of Vernole, and the one in the Otranto area. A rather clear horst, NW-SE oriented, intersects the line which roughly connects Lecce and San Cataldo. The major faults drawn in red are mainly NW-SE oriented, even if some NE-SW oriented faults can be identified too. These findings are in accordance with results found in Grassi et al. [39] and Margiotta and Negri [38].

3.2. Hydrogeological Conceptual Model. In order to define the hydrogeological conceptual model in the study area, the hydrodynamics of the deep aquifer inferred from piezometric head measurements at some of the abovementioned points (96 cross-shaped points in Figure 1) was analysed. The available head values refer to the static level measured when the wells were drilled, between 1952 and 1987, and belong to a database managed at the Laboratory of Hydrogeophysics and Stratigraphy for Natural Hazards of the University of
Salento. Piezometric measurements collected after 1987, mostly belonging to databases managed by the regional authority and other organizations, are not readily available. As such, it was not possible to perform an in-depth evaluation of the evolution of the deep hydrodynamics in time. Consequently, all results reported in the following intend to describe an average hydrogeological state for the deep aquifer on the regional scale.

Figure 4 reports the contour lines obtained by interpolation of the available head values through the kriging method over a grid of square cells $20 \mathrm{~m} \times 20 \mathrm{~m}$ wide.

From contour lines in Figure 4, the following can be inferred about the hydrodynamics of the deep aquifer in the study area. The piezometric head values generally range between about $3 \mathrm{~m}$ above $\mathrm{msl}$ in the central part of the area, and $0 \mathrm{~m}$ with respect to $\mathrm{msl}$ at the southern portion of the coastline. A local maximum (head values up to $4 \mathrm{~m}$ above $\mathrm{msl}$ ) can be detected near Otranto. This could be related to the occurrence of possible superficial aquifers hosted in the overlaying sediments of the MioPliocene units or to the presence of a watershed beyond the coastline or also to the complex geometry of the deep aquifer in that zone, as highlighted in the previous section. As stated above, this was also reported in the previous studies [39, 40], but the reason for this phenomenon has not yet been investigated. By the way, in the absence of detailed lithostratigraphic information and updated piezometric data in this area, no conclusions can be drawn about this occurrence and a deeper insight in this issue on the local scale is necessary.

Arrows in Figure 4 indicate inflow and outflow components across the boundary of the study area, due to sink and source terms. These allow conceptualizing the hydrodynamic behaviour of the deep aquifer and identifying inflows and outflows to the system through the boundaries. These are related to (i) infiltration from the northwestern corner of the active domain, (ii) infiltration through the centraleastern part of the Adriatic coast, (iii) outflow through the remaining part of the coastline, with the exception of the abovementioned coastal area near Otranto, and (iv) outflow through the western boundary. Furthermore, the groundwater budget is also affected by (v) effective infiltration of precipitation $\left(I_{p}\right)$, (vi) the recharge action due to karst depressions locally known as "vore" $(v)$, (vii) evapotranspiration (EVT), and (viii) abstractions for drinking and irrigation purposes $(Q)$. 


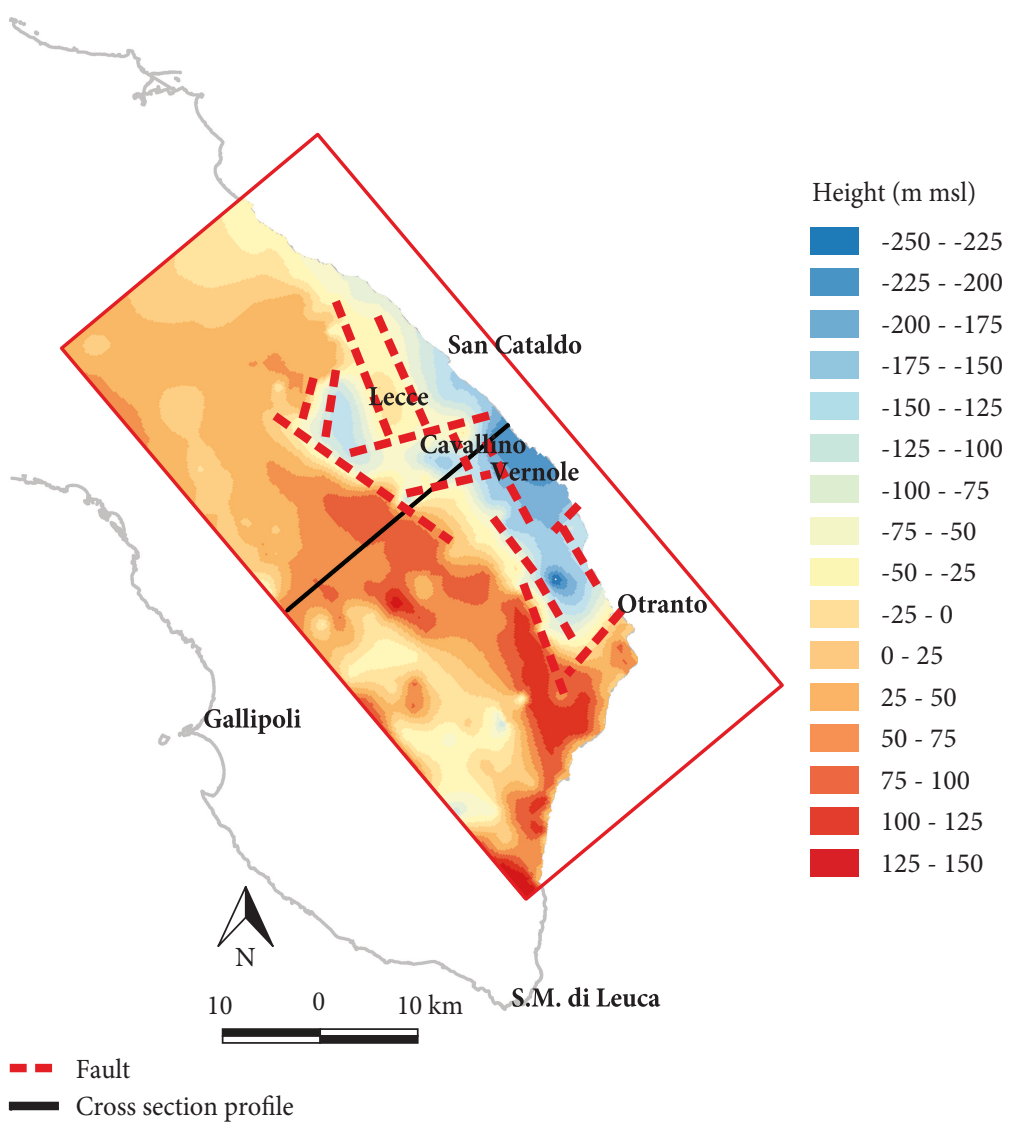

(a)

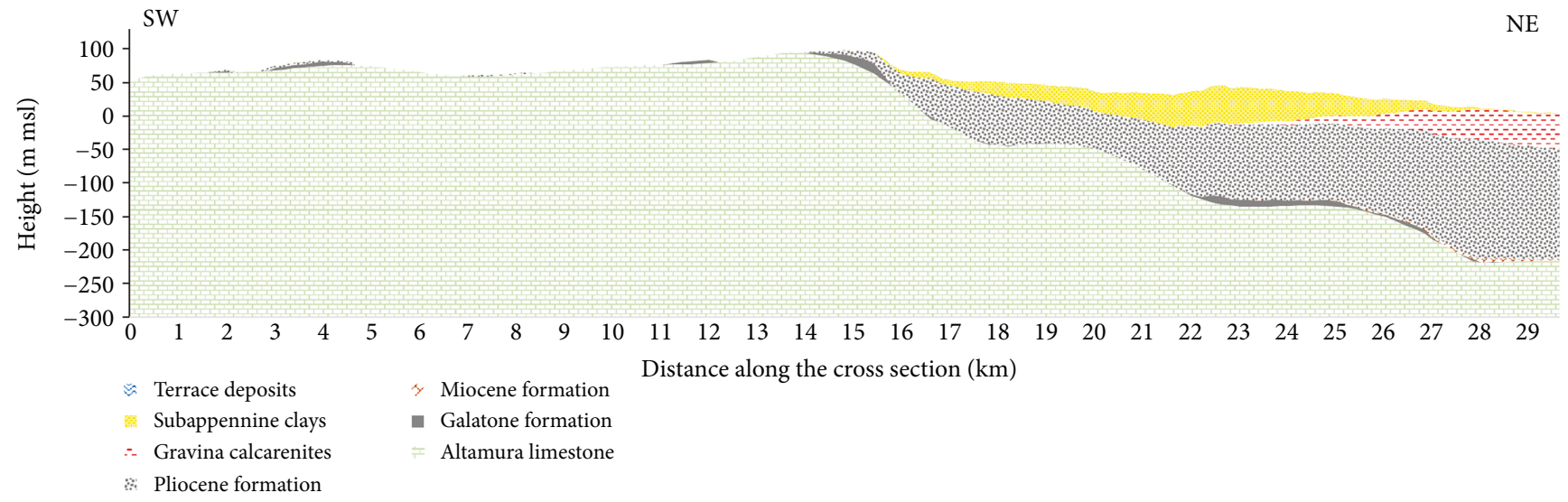

(b)

Figure 3: (a) Top elevation of the deep aquifer. (b) Stratigraphic cross section along the SW-NE profile drawn in subfigure (a).

An important mechanism of recharge for the aquifer is related to the effective infiltration of meteoric waters $\left(I_{p}\right.$ term in Figure 4) through the sediments of the overlying units. To estimate such contribution, evapotranspiration (EVT term in Figure 4) was also taken into account in the way specified below.

First of all, we estimated the average annual precipitation, $P$, by interpolating the average annual rainfall measured between 1952 and 1987 at 12 meteorological stations within the study area [48]. In the period considered, $P$ values range between $600 \mathrm{~mm} /$ year and $800 \mathrm{~mm} /$ year and increase from north-west to south-east.

To estimate EVT, we first determined potential evapotranspiration, based on the average air temperature and solar radiation at the study area, as expressed by the Thornthwaite method [49]. As a result, potential evapotranspiration in the period considered was worth on average $730 \mathrm{~mm} /$ year. We furthermore analysed the land use in the study area [32], which shows that the most widespread crop is olive. As a consequence, potential evapotranspiration 


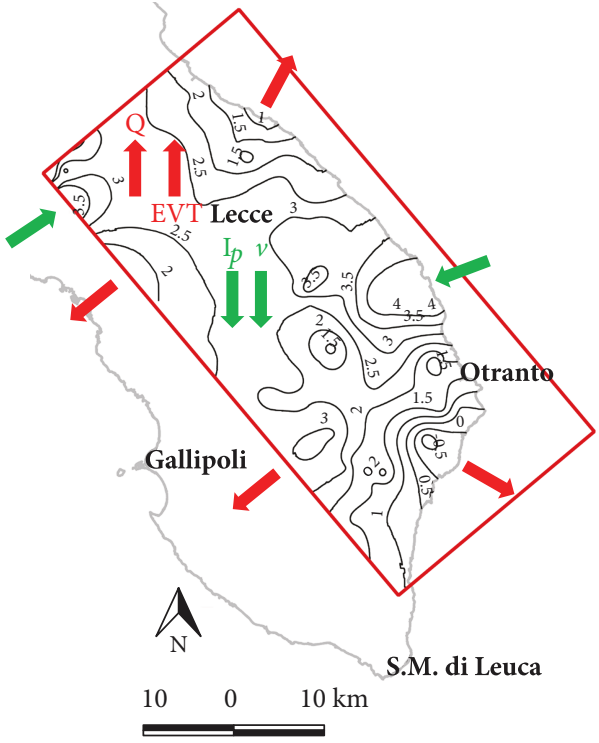

Figure 4: Hydrodynamics of the deep aquifer. Contour lines were obtained by interpolation of the available head data (values in $\mathrm{m}$ above $\mathrm{msl}$; contour line interval: $0.5 \mathrm{~m}$ ). Arrows indicate inflow (green arrows) and outflow (red arrows) to the aquifer across the boundary of the study area and due to sink and source terms.

was multiplied by 0.7 , an average value for the olive $K_{c}$ coefficient [50], resulting in efficient evapotranspiration (EVT) of $510 \mathrm{~mm} /$ year on average.

EVT was so subtracted to $P$ and the hydraulic effect of the identified hydrostratigraphic units was further taken into account in the second step. This was done by multiplying the calculated quantity $(P-\mathrm{EVT})$ by an infiltration coeffi-
TABLe 2: $w_{i}$ coefficients used to calculate $C_{\text {irf }}$ (modified after De Filippis et al. [32]).

\begin{tabular}{lc}
\hline Hydrostratigraphic unit & $w_{i}$ coefficients used to calculate $C_{\text {irf }}$ \\
\hline Altamura limestone & 0.7 \\
Galatone unit & 0.2 \\
Miocene units & 0.4 \\
Pliocene units & 0.5 \\
Gravina calcarenites & 0.7 \\
Subappennine clays & 0.2 \\
Terrace deposits & 0.6 \\
\hline
\end{tabular}

cient, $C_{\text {irf }}$, which takes into account the thicknesses and the hydraulic behaviour of the Altamura limestone and of the units above it, as well as the morphological characteristics of the region.

Specifically, $C_{\text {irf }}$ was calculated as the weighted average of the hydraulic behaviour of the identified hydrostratigraphic units and the thicknesses of such units were adopted as weights. The hydraulic behaviour of the Altamura limestone and of the units above was estimated through coefficients (Table 2) which account also for the morphological characteristics of the region. As an example, the value 0.7 adopted for the Altamura limestone takes into account either the good permeability of the sediments and the presence of hilly areas, mostly located in the southern part of the study area, where the Altamura limestone outcrops and runoff rates are higher than infiltration rates.

As such, $I_{p}$ was calculated according to the following equation:

$$
I_{p}=\left\{\begin{array}{c}
0.7(P-\mathrm{EVT}), \quad \text { where the Altamura limestone outcrops, } \\
P, \quad \text { where major faults (Figure } 3(\mathrm{a})) \text { and "vore" (Figure 5) are located, } \\
(P-\mathrm{EVT}) * C_{\text {irf }}=(P-\mathrm{EVT}) * \frac{\sum_{i=1}^{6} t_{i} w_{i}}{\sum_{i=1}^{6} t_{i}}, \quad \text { elsewhere }
\end{array}\right.
$$

where $t_{i}$ is the thickness of one of the six units above the Altamura limestone and $w_{i}$ is the associated coefficient (Table 2).

As widely reported in the geomorphological maps of the Salento Peninsula (consult, e.g., the regional geoportal SIT Puglia; http://www.sit.puglia.it/), the occurrence of karst sinkholes is widespread in the region. These are locally known as "vore" and contribute to the recharge component of the deep aquifer ( $v$ term in Figure 4). 71 "vore" may be located within the study area (Figure 5), and we assumed that the local recharge contributed by these sinkholes was equal to the rainfall rate at the location of each of them.

Abstraction terms ( $Q$ term in Figure 4$)$ were also taken into account. These are mostly intended to meet the water demand for irrigation and drinking purposes. Since several illegal wells can be found in the region and since no monitoring on abstraction rates is performed for the legal ones, these terms were evaluated based on estimations available in Regione Puglia \& Autorità di Bacino della Puglia [27]. According to such estimates, the water needs for irrigation purposes in the Adriatic portion of the Salento Peninsula is about $84.5 \mathrm{Mm}^{3} /$ year. Such rate has been equally distributed among 15 fictitious wells located into the irrigated districts within the study area. Similarly, in the abovementioned report, the total abstraction rate for drinking purposes in the Adriatic part of the Salento Peninsula is estimated to be about $63.8 \mathrm{Mm}^{3} /$ year. This was equally distributed among the 62 legal drinking wells scattered in the study area. Figure 5 shows the location of abstraction wells in the study area. 


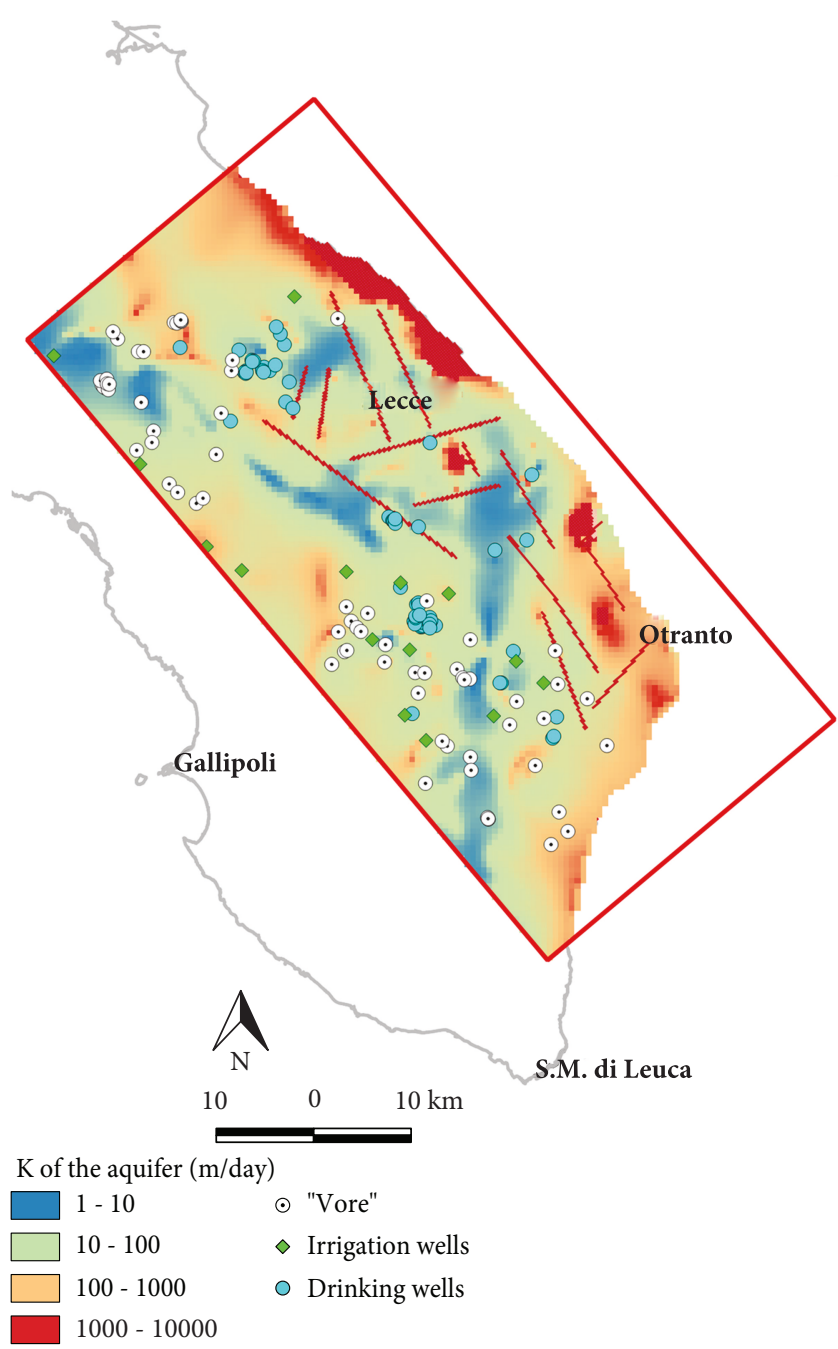

FIGURE 5: Location of irrigation and drinking pumping wells and "vore." The color map refers to the horizontal hydraulic conductivity distribution used for the deep aquifer in the modelling approach.

\subsection{The Modelling Approach}

3.3.1. Objectives and Assumptions. The objective of the present work is to characterize the deep aquifer of the Adriatic portion of the Salento Peninsula from a quantitative point of view, as well as with regard to groundwater salinization, by means of modelling tools for the simulation of groundwater dynamics with MODFLOW-2005 [41] and the saltwater intrusion phenomenon with SEAWAT [42]. The motivations behind such analysis are related to several environmental issues which affect the hydrogeological equilibrium of an aquifer which represents the major source of freshwater in a karstic region characterized by poor surface water potential. The model developed is thus intended to represent a starting point for further enhancements, in view of providing a tool for groundwater management in the area.

Specifically, this analysis is aimed at:

(i) identifying the main processes which affect the groundwater flow dynamics (ii) detecting the areas potentially affected by saltwater intrusion

(iii) identifying the areas where the lack of data prevents a proper comprehension of the hydrogeological processes investigated

(iv) highlighting criticalities which prevent a deep comprehension of the hydrogeological system under exam and set the stage for further investigations

For the aims listed above, the model was developed on a regional scale.

The following assumptions hold true in this paper.

The available head data did not allow investigating the evolution of the aquifer system in time, i.e., to evaluate the change in time of the amount of water stored in the domain. As such, a simplified investigation of the groundwater flow dynamics was carried out, by adopting a steady-state flow approach. With this assumption, we were able to describe an average hydrogeological state for the deep aquifer, i.e., to provide a "picture" of the groundwater flow dynamics, which could represent a starting point for further investigations of transient flow conditions. By the way, even if the flow component was run in steady-state conditions, there is no option in the SEAWAT code to run the transport component as steady state [51]. This is because the transport component in the SEAWAT engine has either stability constraints and/or accuracy requirements that are more restrictive than those for the flow component. As such, each flow time step is further divided into smaller transport steps, during which heads are constant. As a consequence, in the application of the SEAWAT code for the simulation of density-dependent flow, the transport model was run in transient conditions. The same approach was already adopted for another portion of the Salento Peninsula by De Filippis et al. [34].

Another important assumption is the adoption of the "equivalent porous medium" approach, which allows modelling the karst, fractured, deep aquifer of the study area as a continuous, porous medium, instead of a dual-porosity medium. The equivalent porous medium approach involves the replacement of the fractured medium by a representative continuum in which spatially defined values of its hydraulic properties can be assigned [52, 53]. This approach is valid as long as the fracture spacing is sufficiently dense that the fractured medium acts in a hydraulically similar fashion to granular porous media. Besides the density of fractures and the degree of interconnection among them, the spatial scale of the analysis is fundamental for this choice. As stated in Scesi and Gattinoni [54], treating a karst, fractured medium like an equivalent porous medium can be justified in case of a large scale analysis. In such case, the equivalent porous medium approach can provide reliable results if the scope of the analysis is to infer the groundwater flow dynamics and flow-related processes on a large scale.

The equivalent porous medium approach is being widely adopted to simulate groundwater flow in karst systems all over the world $[46,55]$ and in the region under exam [28, 31-36]. 
In this contribution, we made a step forward with respect to the previous modelling studies referred to the deep aquifer of the Salento Peninsula. As stated in Scesi and Gattinoni [54], indeed, the optimal solution to model the behaviour of karst aquifers is to use the equivalent porous medium approach accounting also for the occurrence of structural features (e.g., fractures), which have an important role on the hydrodynamics of such systems. To accomplish this task, we modelled the main fractures recognized on the regional scale (red dotted lines in Figure 3(a)) as zones which contribute higher infiltration rates to the aquifer system.

3.3.2. Groundwater Flow Model Setup. The groundwater flow model was developed by applying the finite-difference approach adopted in MODFLOW-2005 [41] for porous aquifers. To this aim, at the scale of the present analysis, we assumed that the sediments of the Altamura limestone are characterized by a high fracture density and that fractures have small openings. With this assumption, it is possible to treat the deep, karst aquifer under exam as an equivalent porous medium. In addition, the role of major fractures was modelled by introducing zones where higher infiltration rates occur. Further details will be provided below.

The MODFLOW model was set up and run using FREEWAT [43-45] as a graphical user interface integrated in QGIS [56]. The FREEWAT platform allows simulating several water-related processes (e.g., hydrodynamics, solute transport, and conjunctive use of ground- and surface-water) for integrated water management, by coupling the power of GIS tools for spatial data analysis and that of free and open source numerical codes (e.g., MODFLOW and MODFLOW-related programs).

The study area was discretized using a rotated, regular grid made of square cells $200 \mathrm{~m} \times 200 \mathrm{~m}$ wide. For the aims of the groundwater flow model, the deep aquifer was represented using a single model layer extending from the top surface reported in Figure 3(a) to $500 \mathrm{~m}$ below msl. As explained in the next section dedicated to saltwater intrusion, such layer was then discretized through 7 sublayers, in order to properly simulate the hydrodynamic dispersion mechanism, which occurs on a finer scale with respect to the advection process.

For the horizontal hydraulic conductivity of the model layer, the distribution obtained by inverse calibration by $\mathrm{De}$ Filippis et al. [32] was used. Such distribution was obtained through the application of the Comparison Model Method (CMM) [57-60], which is based on the solution of a forward problem for a "comparison model," namely, with a hypothetical (often uniform) conductivity field. The fluxes computed for the "comparison model" are assumed to be a good approximation of the "real" ones, estimated as the product of the "real" transmissivities and the hydraulic gradients inferred from interpolation of field data. Then, the "real" hydraulic conductivity field can be obtained from this comparison. Figure 5 shows values ranging $10-10^{2} \mathrm{~m} /$ day inland, while values of the order of $10^{3}-10^{4} \mathrm{~m} /$ day were estimated along the coastline. As stated above, a step forward was made to account for major faults in the study area (red dotted lines in Figure 3(a)). In this regard, the highest $K$ values (of the order of $10^{4} \mathrm{~m} /$ day) were also set along the profiles of such faults, in order to model zones where higher infiltration rates occur.

We further assumed that the aquifer presented vertical anisotropy only, by assuming for the vertical hydraulic conductivity values equal to $1 / 10$ of the horizontal one.

In order to define boundary conditions, the contour lines reported in Figure 4 were analysed. Specifically, the inflow/outflow components through the western boundary were represented as head-dependent boundary conditions through the application of the General Head Boundary (GHB) MODFLOW package [41]. The same package was also applied to reproduce the hydraulic contact with the Adriatic Sea along the coastline. To this aim, different pieces of the coast were distinguished, and the contact between the deep aquifer and the sea at each piece was supposed to occur between $0 \mathrm{~m}$ and $200 \mathrm{~m}$ far from the coastline. Furthermore, the northern boundary of the study area was treated as a no-flow boundary. The same was assumed at the base of the model, meaning that no vertical water exchange occurs at the bottom of the deep aquifer.

Source and sink terms related to effective infiltration, local "vore," and abstractions for irrigation and drinking purposes, respectively, were estimated as explained in the previous subsection (Figure 5). The Recharge MODFLOW package was applied for effective infiltration, as specified in the above section. The Well MODFLOW package was used for "vore" (positive flow rates) and abstraction wells (negative flow rates).

The model was run over a steady-state stress period 365 days long.

A sensitivity analysis was performed using UCODE_ 2014 [61] integrated in the FREEWAT platform as well. Specifically, the Composite Scaled Sensitivity (CSS) index [62] was evaluated to assess the information content of the whole head dataset (cross-shaped points in Figure 1) for the estimation of the most sensitive parameters. Figure 6 reports results of the sensitivity analysis, which included the following parameters:

(i) The recharge flux related to effective infiltration ( $\mathrm{rch}$ in Figure 6)

(ii) The abstraction rates for irrigation and drinking purposes (wells in Figure 6)

(iii) The horizontal and vertical components of the hydraulic conductivity of the deep aquifer ( $\mathrm{kxx}$ and kzz in Figure 6)

(iv) The inflow/outflow terms related to the GHB boundary condition (ghb_cond in Figure 6)

As highlighted in Figure 6, the model fit is insensitive to variations of the vertical hydraulic conductivity, meaning that the available head data does not contain enough information for the estimation of the kzz parameter. On the contrary, the most sensitive parameters are the recharge flux (rch) and the horizontal component of the hydraulic conductivity ( $\mathrm{kxx})$, while the sensitivities of 


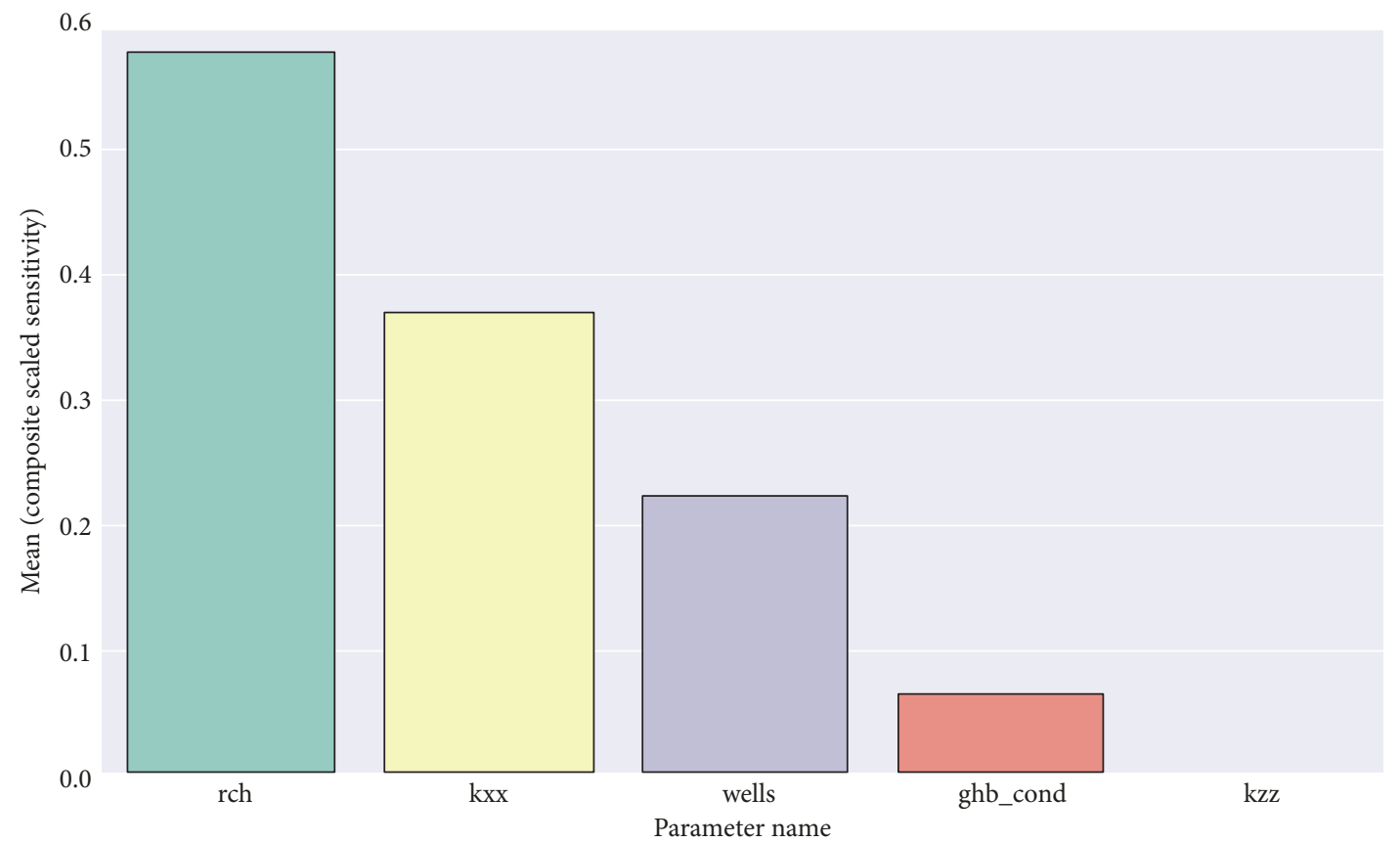

Figure 6: Values of the Composite Scaled Sensitivity for the model parameters considered as the most sensitive ones.

parameter wells are worth about $1 / 3$ of the maximum CSS and the sensitivity of ghb_cond is worth about $1 / 9$ of the maximum CSS. As such, the parameter kzz was not included in the trial-and-error calibration of the remaining parameters, whose results are reported in the following section.

3.3.3. Density-Dependent Flow Model Setup. In order to get an insight on groundwater salinization, the groundwater flow model was applied to simulate the saltwater intrusion phenomenon. This was accomplished by developing a densitydependent flow model to assess the extent of lateral intrusion and vertical upconing of saltwater, applying the SEAWAT code [42], which is integrated within the FREEWAT platform as well.

To this aim, the deep aquifer was further discretized through 7 sublayers with equal thickness, in order to properly simulate the hydrodynamic dispersion mechanism, which occurs at a finer scale with respect to the advection process [51].

The following parameters were set for the deep aquifer to solve the solute transport component:

(i) Effective porosity: 0.1

(ii) Coefficient of molecular diffusion: $10^{-5} \mathrm{~m}^{2} /$ day

(iii) Longitudinal dispersivity: $200 \mathrm{~m}$

(iv) Transverse dispersivity: $20 \mathrm{~m}$

(v) Vertical dispersivity: $20 \mathrm{~m}$

A concentration of $38 \mathrm{~g} / \mathrm{l}$ was assigned at cells along the coastline, where the GHB MODFLOW package was applied.
Concentration values were left free to vary at the remaining grid cells.

The model was run over 10 years. At this stage, it was not possible to calibrate the model, due to the lack of good-quality concentration data.

\section{Results and Discussion}

4.1. Results of the Groundwater Flow Model. As mentioned in the previous section, the groundwater flow model was calibrated adopting a trial-and-error approach over the most sensitive parameters. All parameters reported in Figure 6, except for kzz, were included in the calibration procedure, aimed at improving the model fit with respect to the observed piezometric head values measured at the cross-shaped points in Figure 1. The scatter plot of observed vs. simulated head values is reported in Figure 7 along with statistics on residuals (i.e., the difference between observed and simulated values).

We can infer from Figure 7 that all points are within the 90\% confidence interval. Furthermore, the model fit differs for about $0.04 \mathrm{~m}$ on average from the observations, with a standard deviation of $0.35 \mathrm{~m}$. Also, the absolute residual mean is about $0.29 \mathrm{~m}$, with a standard error of the estimate of about $0.04 \mathrm{~m}$.

Figure 8(a) reports the simulated piezometric head distribution. With respect to contour lines reported in Figure 4, we can infer that the general trend (i.e., inflow and outflow components) was reproduced by the model. Of course, since abstractions in the model were derived from assumptions and estimates, the local minima displayed in Figure 4 could not be reproduced. Despite this, taking into account the statistics reported in Figure 7, model results can be considered satisfactory in reproducing the involved processes. 


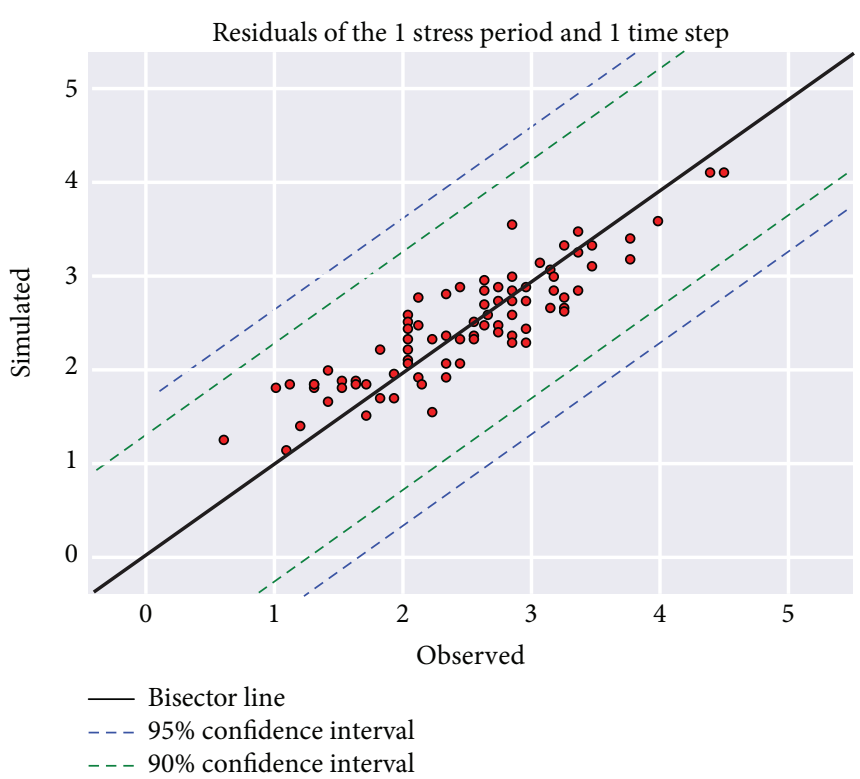

(a)

\begin{tabular}{l|l}
\multicolumn{1}{c|}{ Residual statistics } & Value \\
\hline Residual count & 96 \\
Mean & 0.04 \\
SD & 0.35 \\
Min & -0.66 \\
Max & 0.81 \\
Absolute residual mean & 0.29 \\
Standard error of the estimate & 0.04 \\
Residual RMS & 0.04 \\
Normalized RMS & 0.04 \\
Pearson correlation coefficient & 0.01
\end{tabular}

(b)

FIGURE 7: Comparison between observed and simulated head values and statistics on residuals.

Through interpreting the map in Figure 8(a) with the support of the model budget reported in Table 3, the following can be stated:

(i) Inflow and outflow terms can be identified through the GHB boundaries of the active domain. Altogether, inflow terms are worth about $8.24 \mathrm{Mm}^{3} /$ day, including the inflow occurring across the coast near Otranto; outflow terms are worth about $10.22 \mathrm{Mm}^{3} /$ day

(ii) The source term related to effective infiltration contributes to the overall budget with about $2.48 \mathrm{Mm}^{3} /$ day

(iii) The pumped groundwater is about $0.52 \mathrm{Mm}^{3} /$ day
Regarding the high head values recorded north of Otranto (up to $4.2 \mathrm{~m}$ above msl), we must notice that these have been repeatedly highlighted in the past, e.g., by Zorzi and Reina [40], Grassi et al. [39], Giudici et al. [28], and De Filippis et al. [32]. By the way, possible reasons for this phenomenon have never been explored. Cotecchia et al. [31] highlight three areas characterized by high head values along the NE-SW oriented line which roughly connects Otranto and a zone south of Gallipoli. A similar finding has been reported recently by Fidelibus and Pulido-Bosch [63]. This line corresponds to a major discontinuity feature, and the high head values detected would therefore have a structural cause and would generate drainage both towards the north and the south, determining a hydrogeological watershed. In any case, the presence of this watershed, with particular reference to the one located north of Otranto, puts in crisis the models [64] according to which the Salento Peninsula is almost entirely crossed by a hydrogeological watershed NW-SE oriented in its central part.

In any further study dedicated to this topic, a very important aspect that must be taken into account is linked to the eustatic oscillations that have affected the Salento Peninsula in the past 20000 years [65]. In fact, it cannot be excluded that the high head values detected north of Otranto are linked to the presence of freshwater trapped in tectonic grabens, due to the rising of the sea level [66-69] and for the presence of impermeable Miocene and Pliocene clayey deposits.

Taking steps from the previous theories [70], a recent study [71] analysed the occurrence of offshore fresh groundwater at 27 coastal areas worldwide, using an analytical model for estimating the extent of such occurrence. Two main drivers of such phenomenon are identified: (1) the presence of entrapped paleofreshwater during periods characterized by lower sea levels and (2) freshwater discharge from onshore aquifers to subsea aquifers under current sea level conditions. In both cases, the onshore-offshore coastal aquifer is conceptualized with an aquitard extending from the coastline offshore, which prevents vertical exchange between freshwater and saltwater, and a potentiometric surface which declines to the sea level offshore, far from the coastline. Based on the review of the 27 case studies, seven conceptual models were developed to show in both cases (options (1) and (2) above) the effects of groundwater pumping, which may result in pumping freshwater or saltwater according to the equilibrium of the interface in the offshore part of the aquifer.

The groundwater flow model was validated using a dataset of piezometric head values collected at 6 points in 2018 (Figure 8(b)). According to residuals statistics, the model fit differs for about $0.07 \mathrm{~m}$ on average from the observations, with a standard deviation of about $0.22 \mathrm{~m}$. Also, the absolute residual mean is about $0.20 \mathrm{~m}$, with a standard error of the estimate of about $0.10 \mathrm{~m}$. This confirms that the model developed represents a valuable tool and a good starting point for further enhancements, as it is able to reproduce the physical processes for which the available observations contain information. 


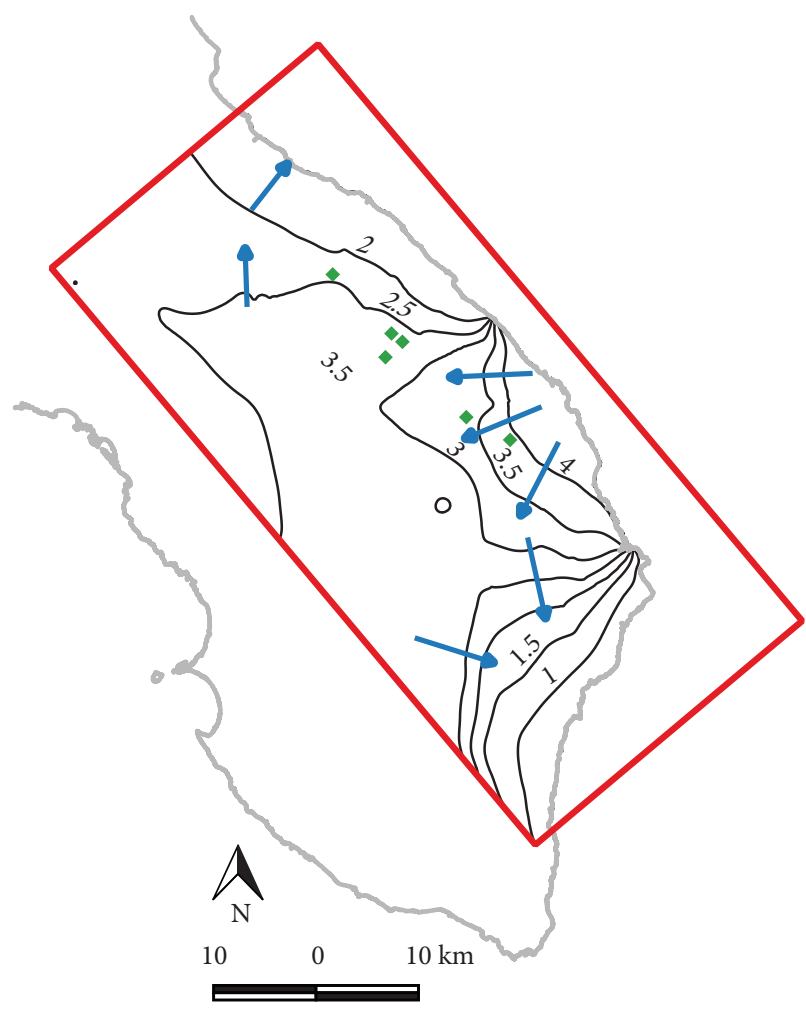

(a)

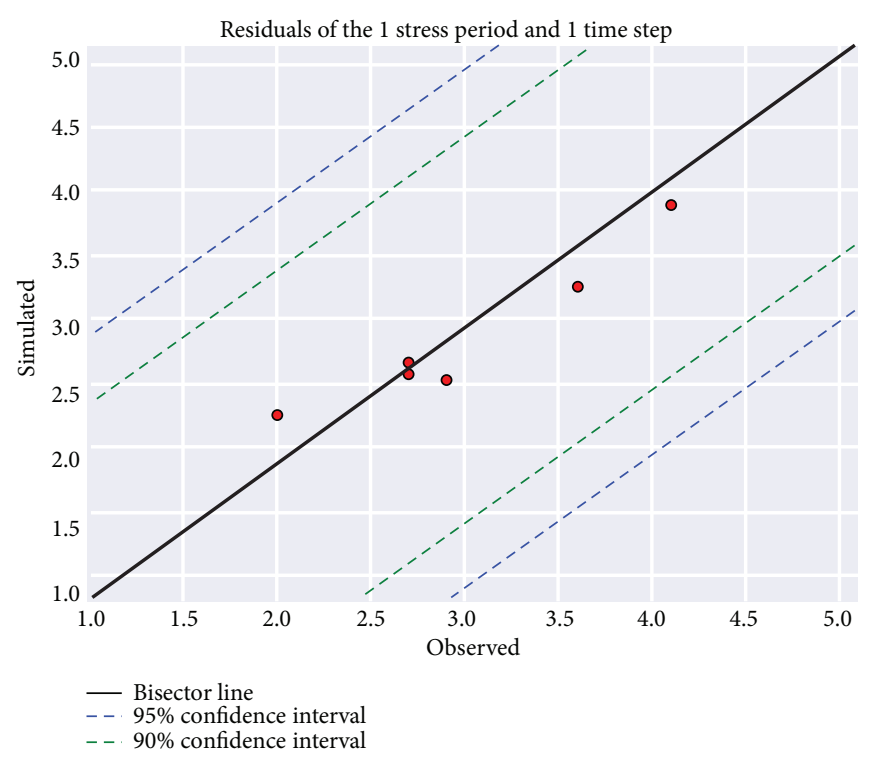

\begin{tabular}{l|l}
\multicolumn{1}{c}{ Residual statistics } & Value \\
\hline Residual count & 6 \\
Mean & -0.07 \\
SD & 0.22 \\
Min & -0.29 \\
Max & 0.35 \\
Absolute residual mean & 0.20 \\
Standard error of the estimate & 0.10 \\
Residual RMS & 0.07 \\
Normalized RMS & 0.07 \\
Pearson correlation coefficient & 0.03
\end{tabular}

(b)

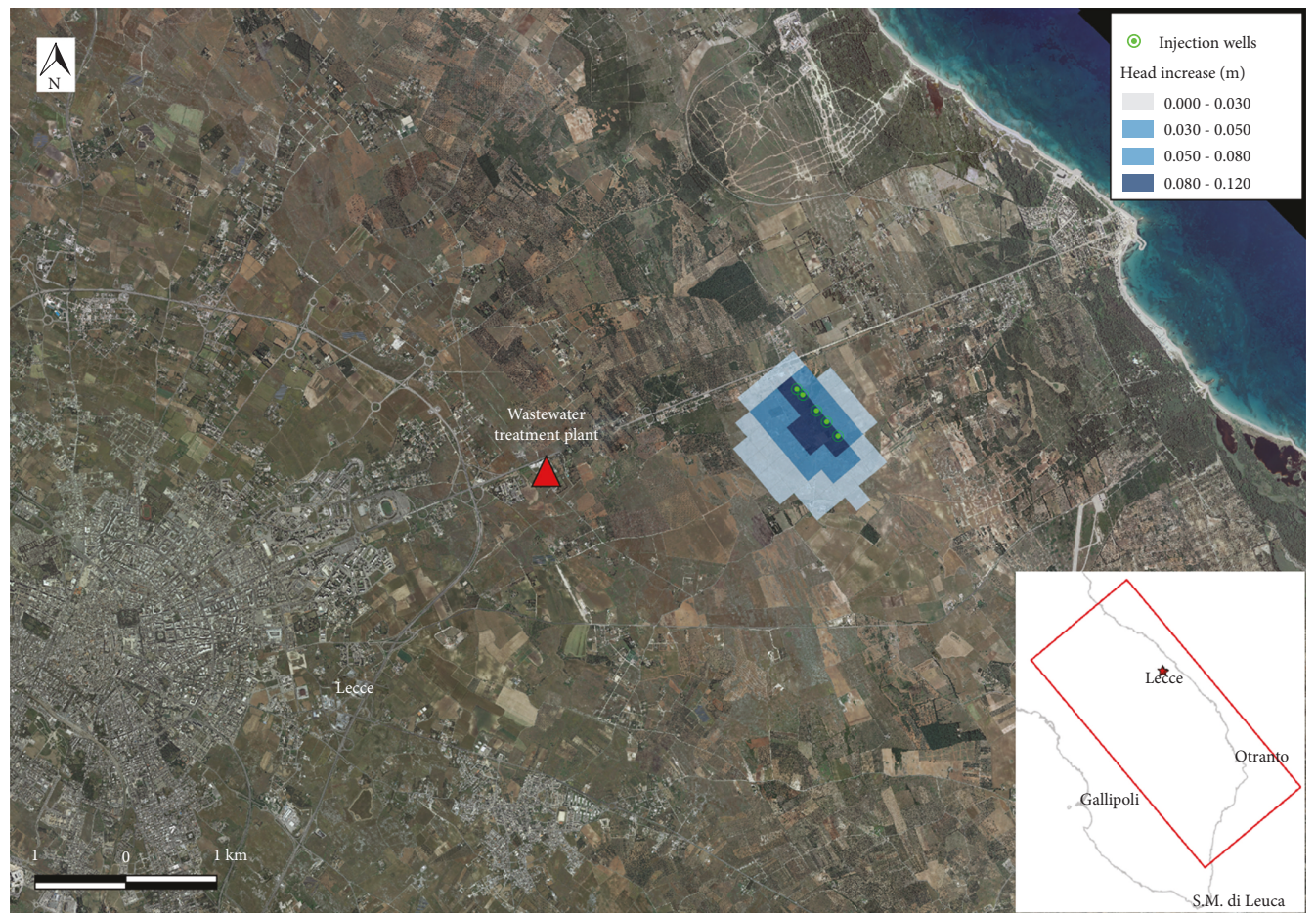

(c)

FIGURE 8: (a) Simulated piezometric head (values of contour lines are expressed in m above msl; contour line interval: $0.5 \mathrm{~m}$; arrows reproduce the flow lines). Green dots indicate the location of wells used for model validation. (b) Results of model validation and statistics on residuals. (c) Effects of the application of a MAR scheme. 
TABLE 3: Simulated water budget.

\begin{tabular}{|c|c|c|c|c|c|}
\hline Inflow terms & $\begin{array}{l}\text { Simulated flow } \\
\text { rate }\left(\mathrm{Mm}^{3} / \text { day }\right)\end{array}$ & $\begin{array}{l}\% \text { over the } \\
\text { total inflow }\end{array}$ & Outflow terms & $\begin{array}{l}\text { Simulated flow } \\
\text { rate }\left(\mathrm{Mm}^{3} / \text { day }\right)\end{array}$ & $\begin{array}{l}\% \text { over the } \\
\text { total outflow }\end{array}$ \\
\hline Recharge due to "vore" & $2.73 * 10^{-3}$ & Negligible & & & \\
\hline Effective infiltration & 2.48 & 23 & & & \\
\hline \multirow[t]{2}{*}{ Inflow through model boundaries } & 8.24 & 77 & Outflow through model boundaries & 10.22 & 95 \\
\hline & & & Abstractions & 0.52 & 5 \\
\hline Total & 10.74 & & Total & 10.74 & \\
\hline
\end{tabular}

The groundwater flow model was applied to simulate the effects of a MAR facility on the quantitative status of the deep aquifer in the study area, as well as with regard to groundwater salinization. Specifically, an increase of the piezometric head in the deep aquifer was assessed, by setting up five injection wells located about $3 \mathrm{~km}$ far from a wastewater treatment plant in Lecce and about $4 \mathrm{~km}$ far from the coastline. Each of these wells was assigned a recharge rate of $40 \mathrm{l} / \mathrm{s}$, resulting in a total infiltration rate of 200 1/s (about $6.31 \mathrm{Mm}^{3} /$ year). Based on estimates made by the local land reclamation authority, this corresponds to the yearly volume of water treated in the wastewater treatment plant and discharged towards the sea.

According to this scenario with the infiltration wells in operation, an increase in the simulated piezometric head was simulated. Such increase is worth about $0.12 \mathrm{~m}$ at the location of the recharge wells. Furthermore, an increase of at least $0.03 \mathrm{~m}$ would be recorded over an area of about $2.3 \mathrm{~km}^{2}$ (Figure $8(\mathrm{c})$ ).

4.2. Results of the Density-Dependent Flow Model. The extent of the saltwater intrusion phenomenon is presented in Figure 9 in terms of concentration distribution obtained at each sublayer in the density-dependent flow model. Such distribution is reported at different depths, and it is shown either in the horizontal or vertical directions, in order to assess the lateral extent and the vertical upconing of saltwater. Moreover, to make Figure 9(a) more readable, a concentration threshold was set to $0.5 \mathrm{~g} / \mathrm{l}$, as suggested in Cotecchia et al. [31].

We can infer from Figure 9(a) that saltwater gradually intrudes from the coast towards inland, driven by the hydrodynamic dispersion process. Also, the width of the strip where concentration values higher than $0.5 \mathrm{~g} / \mathrm{l}$ were simulated is about $5 \mathrm{~km}$ in sublayer 1 , while the intrusion front advances up to more than $6 \mathrm{~km}$ from the coast inland in sublayer 7 . As a consequence of comments and results presented above, we can notice that the inflow component simulated in the Otranto area makes saltwater intrusion to affect that area to a higher extent with respect to the rest of the coastline. Furthermore, the effects of the regional faults taken into account within the model are clearly highlighted.

Figure 9(b) reports concentration values simulated for the deep aquifer up to $500 \mathrm{~m}$ below msl along a SW-NE profile near Lecce, crossing one of the regional faults. This cross section confirms the above results and clearly shows the effects of faults, which would cause upconing of seawater from below the bottom of the model.
Cross sections reported in Figure 10 are drawn along a profile which crosses one of the injection wells set in the model for MAR purposes. In particular, Figures 10(a) and 10(b) report concentration values simulated for the deep aquifer up to $500 \mathrm{~m}$ below msl before and after the application of the injection MAR wells, respectively. The location of an injection well is reported as well in Figure 10(b). At that location, the cone of injected freshwater results from the specific boundary condition set in the density-dependent flow model. With respect to the scenario reported in Figure 10(a), we can infer that setting in operation such a MAR scheme would result in containing the lateral saltwater intrusion phenomenon. In such case, the intrusion front would retreat by about $1 \mathrm{~km}$.

\section{Conclusions}

This paper focuses on the Adriatic portion of the Salento Peninsula, where a major freshwater resource is represented by the deep, karst, coastal aquifer hosted in limestone sediments. Such aquifer is particularly sensitive to human impacts, climate change, and saltwater intrusion. Taking steps from the previous works $[28,32]$, the deep aquifer in the study area was characterized by means of modelling tools for the simulation of groundwater dynamics and the saltwater intrusion phenomenon.

The interpolation of the available piezometric data over the study area allowed conceptualizing the hydrodynamic behaviour of the deep aquifer and identifying inflows and outflows to the system through the boundaries and source/ sink terms, which were then implemented in a groundwater flow model by applying specific MODFLOW packages.

The groundwater flow model was developed adopting two main limitations: (a) the model was run under steadystate conditions, due to the lack of piezometric data regularly recorded in time, and (b) the karst medium was modelled with an equivalent porous medium approach. A remarkable advancement with respect to the previous models included the representation of major structural features of the karst environment (i.e., faults), which affect the groundwater flow dynamics on the regional scale. These were modelled introducing zones where high infiltration rates occur.

As a result of the groundwater flow model, the budget terms mentioned above were quantified and the piezometric head distribution describing the hydrodynamics of the deep aquifer during an average hydrogeological year was obtained.

Particular attention deserves the high head values recorded north of Otranto which are responsible for the 

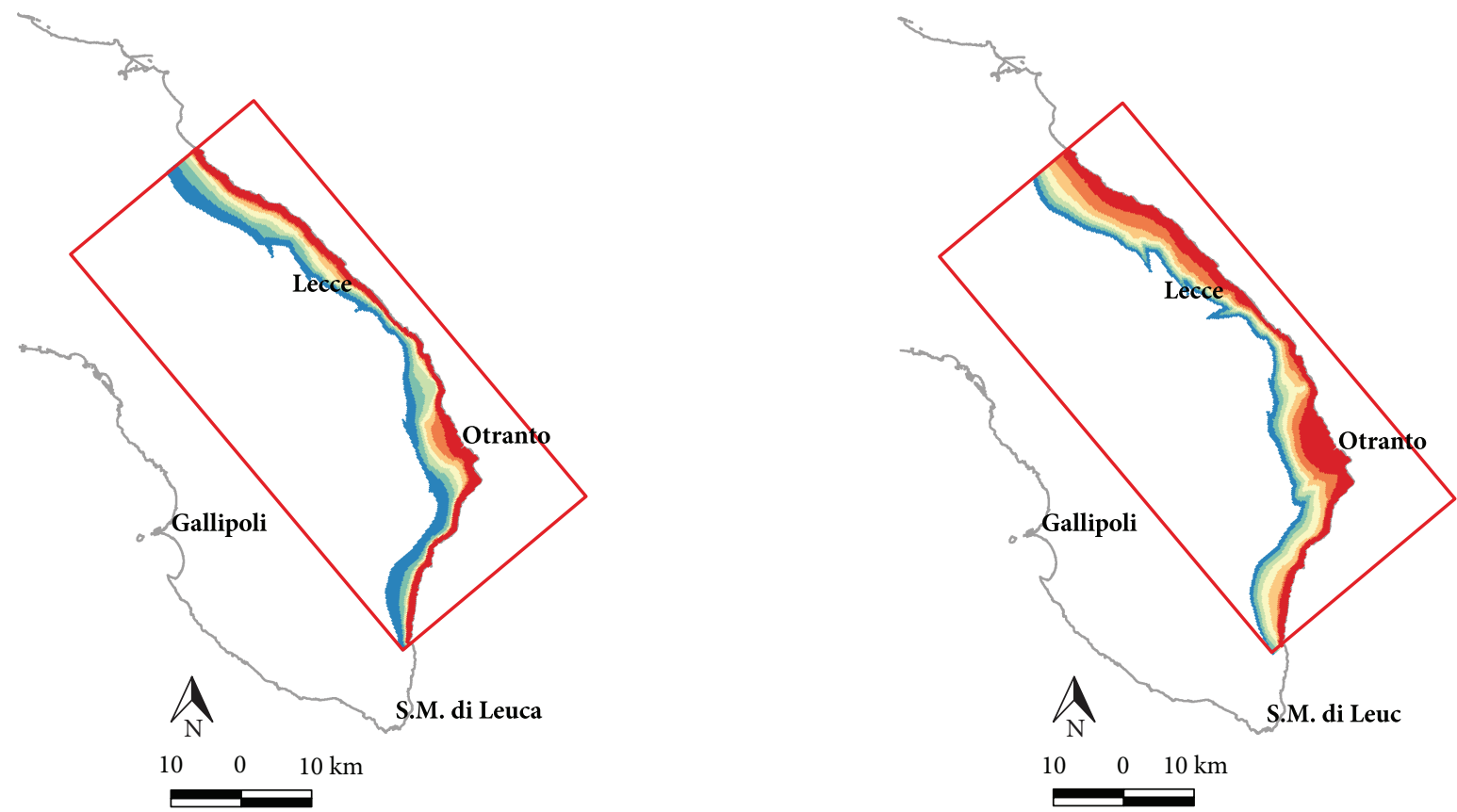

Salt concentration $(\mathrm{g} / \mathrm{l})$

\begin{tabular}{l|l}
$0-5$ & $20-25$ \\
$5-10$ & $25-30$ \\
$10-15$ & $30-38$ \\
$15-20$ &
\end{tabular}

(a)
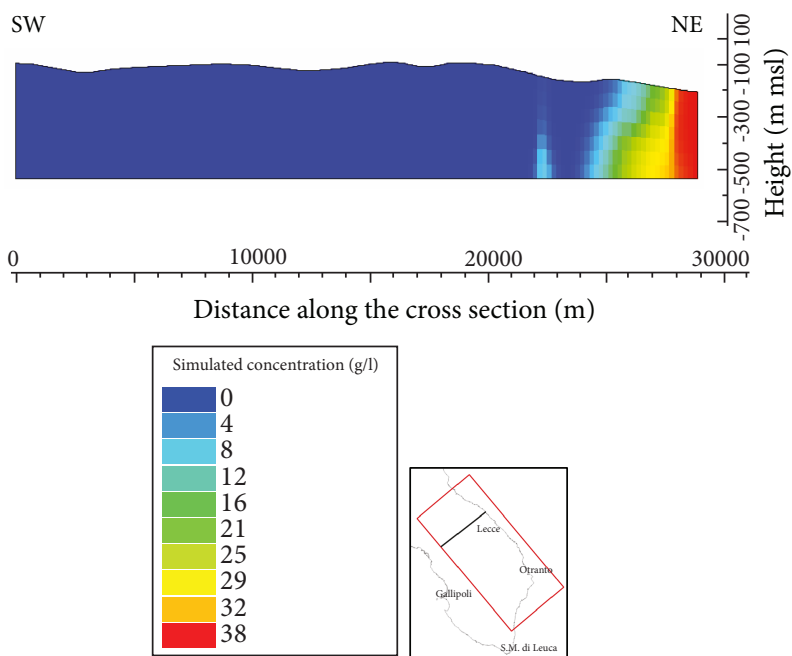

(b)

FIgURE 9: (a) Lateral saltwater intrusion simulated for sublayer 1 (left side) and for sublayer 7 (right side). (b) Vertical cross section along a SW-NE profile near Lecce.

infiltration term through the central-eastern part of the Adriatic coast. Such phenomenon has been widely highlighted in the past, but the causes still remain pretty uncertain. A discussion has been reported in this regard, about the role of structural features and of eustatic variations in the region. By the way, confirming the presence of such critical area puts in crisis all models according to which a hydrogeological watershed is clearly identified at the center of the Salento Peninsula. Of course, a thorough explanation for this phenomenon has still to be found, but this discussion is a starting point for further research. Few lithostratigraphic and piezometric data, indeed, are available, but the results obtained deserve attention and set the stage for further investigations involving the drilling of new piezometers, whose measured values would help the understanding of the deep groundwater dynamics.

The groundwater flow model was applied to develop a density-dependent flow model for the assessment of the 


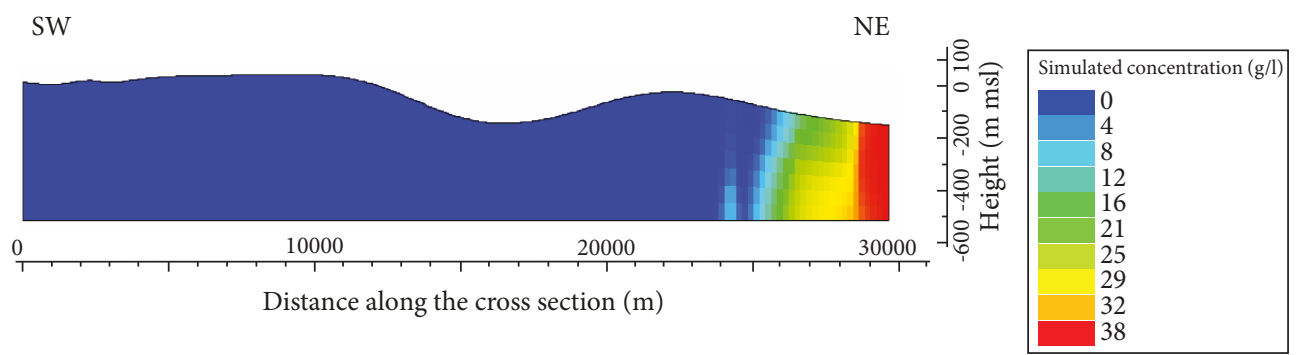

(a)
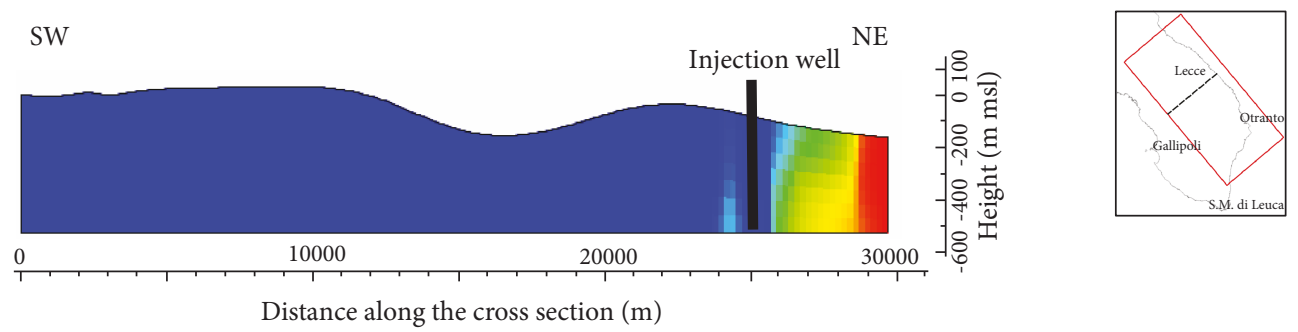

(b)

FIGURE 10: Vertical cross section along the SW-NE profile across one of the injection wells. (a) With injection wells inactivated. (b) With injection wells in operation.

saltwater intrusion phenomenon. With respect to the previous works, where a sharp-interface approach was adopted, the SEAWAT code was applied instead to assess the extent of lateral intrusion and vertical upconing of saltwater, resulting in worsening of irrigation and drinking water quality. The model was run over 10 years and allowed assessing that salt concentration values higher than $0.5 \mathrm{~g} / \mathrm{l}$ would be detected up to $6 \mathrm{~km}$ from the coast inland. Results of the SEAWAT model allowed highlighting the role of regional faults in the upconing of saltwater and inferring that the critical zone near Otranto deeps particular attention as it would be affected by saltwater to a higher extent with respect to the remaining areas along the coastline.

A further application of these models consisted in simulating the effects induced by a MAR facility consisting in injecting treated wastewater produced by the treatment plant located in Lecce. This allowed evaluating the resulting piezometric head increase (up to $12 \mathrm{~cm}$ at the location of the injection wells) and the changes induced in the advancement of the saltwater intrusion front (this would retreat by about $1 \mathrm{~km}$ at the location of the injection wells). Such results make the methodology adopted a valuable tool, which can be replicated to propose further insights along the coast, testing the effectiveness of using rainwater and improving infiltration through the local "vore."

The methodology presented in this paper has a valuable importance from the environmental point of view, as it allowed assessing the quantitative status of the major freshwater resource available in the study area and in the whole Salento Peninsula and drawing conclusions about groundwater salinization. Such methodology allowed testing management and protection strategies based on efficient and up-to-date techniques, such as MAR solutions. Model results also allowed identifying areas where the lack of data prevents a proper comprehension of the hydrogeological processes investigated, thus representing supporting tools for planning further monitoring campaigns. In this view, the research activities presented in this paper represent an advancement with respect to the previous works and lay the basis for further scientific investigations on this topic, aimed at characterizing the hydrogeological equilibrium of the deep aquifer in transient conditions and at undertaking further analysis on local scale.

\section{Data Availability}

The SpatiaLite database of the numerical model developed using the FREEWAT interface is available upon request.

\section{Disclosure}

This paper exploits results of the research activity carried on at the Laboratory of Hydrogeophysics and Stratigraphy for Natural Hazards of the Department of Biological and Environmental Sciences and Technologies of the University of Salento (Lecce, Italy), managed by prof. Sergio Luigi Negri. Such paper takes steps from the MSc thesis of Claudia Branca "Implementazione di un Modello di Flusso per la Gestione della Falda Profonda Carbonatica del Salento Adriatico mediante Applicazione della Piattaforma FREEWAT Integrata in GIS" ("Implementation of a Flow Model for Managing the Deep, Karst Aquifer of the Adriatic Part of the Salento Peninsula by Means of the Application of the GIS-Integrated FREEWAT Platform") (available in Italian language upon request).

\section{Conflicts of Interest}

The authors declare that there is no conflict of interest regarding the publication of this paper. 


\section{Acknowledgments}

The land reclamation authority "Ugento Li Foggi" is kindly acknowledged for the piezometric data used for model validation and for information provided about flow rates of the wastewater treatment plant located in Lecce. Stefano Grasso and Francesco Caruso (University of Salento) are also acknowledged for their support to this research activity.

\section{References}

[1] W. Cramer, J. Guiot, M. Fader et al., "Climate change and interconnected risks to sustainable development in the Mediterranean," Nature Climate Change, vol. 8, no. 11, pp. 972-980, 2018.

[2] J. M. García-Ruiz, J. I. López-Moreno, S. M. Vicente-Serrano, T. Lasanta-Martínez, and S. Beguería, "Mediterranean water resources in a global change scenario," Earth-Science Reviews, vol. 105, no. 3-4, pp. 121-139, 2011.

[3] J. Lorenzo-Lacruz, C. Garcia, and E. Morán-Tejeda, "Groundwater level responses to precipitation variability in Mediterranean insular aquifers," Journal of Hydrology, vol. 552, pp. 516-531, 2017.

[4] M. Bakalowicz, "Karst and karst groundwater resources in the Mediterranean," Environmental Earth Sciences, vol. 74, no. 1, pp. 5-14, 2015.

[5] A. Hartmann, T. Gleeson, R. Rosolem, F. Pianosi, Y. Wada, and T. Wagener, "A large-scale simulation model to assess karstic groundwater recharge over Europe and the Mediterranean," Geoscientific Model Development, vol. 8, no. 6, pp. 1729-1746, 2015.

[6] N. Alfarrah and K. Walraevens, "Groundwater overexploitation and seawater intrusion in coastal areas of arid and semi-arid regions," Water, vol. 10, no. 2, p. 143, 2018.

[7] B. Tlili-Zrelli, M. Gueddari, and R. Bouhlila, "Spatial and temporal variations of water quality of Mateur aquifer (northeastern Tunisia): suitability for irrigation and drinking purposes," Journal of Chemistry, vol. 2018, Article ID 2408632, 15 pages, 2018.

[8] P. Venetsanou, K. Voudouris, N. Kazakis, and C. Mattas, "Impacts of urbanization, agriculture and touristic development on groundwater resources in the eastern part of Thermaikos Gulf (North Greece): an application of DPSIR model for sustainable development," Eur Water, vol. 51, pp. 313, 2015.

[9] L. Tadić, T. Dadić, and M. Leko-Kos, "Variability of hydrological parameters and water balance components in small catchment in Croatia," Advances in Meteorology, vol. 2016, Article ID 1393241, 9 pages, 2016.

[10] C. Petalas and N. Lambrakis, "Simulation of intense salinization phenomena in coastal aquifers-the case of the coastal aquifers of Thrace," Journal of Hydrology, vol. 324, no. 1-4, pp. 51-64, 2006.

[11] M. A. Somay and Ü. Gemici, "Assessment of the salinization process at the coastal area with hydrogeochemical tools and geographical information systems (GIS): Selçuk plain, Izmir, Turkey," Water, Air, and Soil Pollution, vol. 201, no. 1-4, pp. 55-74, 2009.

[12] M. A. Eissa, H. H. Mahmoud, O. Shouakar-Stash, A. ElShiekh, and B. Parker, "Geophysical and geochemical studies to delineate seawater intrusion in Bagoush area, Northwestern coast, Egypt," Journal of African Earth Sciences, vol. 121, pp. 365-381, 2016.

[13] J. Hammami Abidi, B. Farhat, A. Ben Mammou, and N. Oueslati, "Characterization of recharge mechanisms and sources of groundwater salinization in Ras Jbel coastal aquifer (northeast Tunisia) using hydrogeochemical tools, environmental isotopes, GIS, and statistics," Journal of Chemistry, vol. 2017, Article ID 8610894, 20 pages, 2017.

[14] L. Jarlan, S. Khabba, S. Er-Raki et al., "Remote sensing of water resources in semi-arid Mediterranean areas: the joint international laboratory TREMA," International Journal of Remote Sensing, vol. 36, no. 19-20, pp. 4879-4917, 2015.

[15] D. Boubaya, "Combining resistivity and aeromagnetic geophysical surveys for groundwater exploration in the Maghnia plain of Algeria," Journal of Geological Research, vol. 2017, Article ID 1309053, 14 pages, 2017.

[16] T. McCormack, Y. O’Connell, E. Daly, L. W. Gill, T. Henry, and M. Perriquet, "Characterisation of karst hydrogeology in Western Ireland using geophysical and hydraulic modelling techniques," Journal of Hydrology: Regional Studies, vol. 10, pp. 1-17, 2017.

[17] A. Satriani, A. Loperte, V. Imbrenda, and V. Lapenna, "Geoelectrical surveys for characterization of the coastal saltwater intrusion in Metapontum forest reserve (southern Italy)," International Journal of Geophysics, vol. 2012, Article ID 238478, 8 pages, 2012.

[18] C. Leduc, A. Pulido-Bosch, and B. Remini, "Anthropization of groundwater resources in the Mediterranean region: processes and challenges," Hydrogeology Journal, vol. 25, no. 6, pp. 1529-1547, 2017.

[19] P. Dillon, P. Stuyfzand, T. Grischek et al., "Sixty years of global progress in managed aquifer recharge," Hydrogeology Journal, vol. 27, no. 1, pp. 1-30, 2019.

[20] C. Masciopinto, M. Vurro, V. N. Palmisano, and I. S. Liso, "A suitable tool for sustainable groundwater management," Water Resources Management, vol. 31, no. 13, pp. 4133-4147, 2017.

[21] J. P. Bonilla Valverde, C. Blank, M. Roidt, L. Schneider, and C. Stefan, "Application of a GIS multi-criteria decision analysis for the identification of intrinsic suitable sites in Costa Rica for the application of managed aquifer recharge (MAR) through spreading methods," Water, vol. 8, no. 9, 2016.

[22] N. Kazakis, "Delineation of suitable zones for the application of managed aquifer recharge (MAR) in coastal aquifers using quantitative parameters and the analytical hierarchy process," Water, vol. 10, no. 6, 2018.

[23] N. Kazakis, M. Spiliotis, K. Voudouris, F. K. Pliakas, and B. Papadopoulos, "A fuzzy multicriteria categorization of the GALDIT method to assess seawater intrusion vulnerability of coastal aquifers," Science of the Total Environment, vol. 621, pp. 524-534, 2018.

[24] O. Tzoraki, Z. Dokou, G. Christodoulou, P. Gaganis, and G. Karatzas, "Assessing the efficiency of a coastal Managed Aquifer Recharge (MAR) system in Cyprus," Science of the Total Environment, vol. 626, pp. 875-886, 2018.

[25] G. De Filippis, S. Margiotta, S. Negri, and M. Giudici, "The geothermal potential of the underground of the Salento peninsula (southern Italy)," Environmental Earth Sciences, vol. 73, no. 11, pp. 6733-6746, 2015.

[26] M. Polemio, P. P. Limoni, D. Mitolo, and R. Virga, "Il degrado qualitativo delle acque sotterranee pugliesi," Giornale di Geologia Applicata, vol. 3, pp. 25-31, 2006. 
[27] Regione Puglia and Autorità di Bacino della Puglia, Aggiornamento del Bilancio Idrogeologico dei Corpi Idrici Sotterranei della Regione Puglia. All. 4.10 alla Relazione Finale, 2011, in Italian.

[28] M. Giudici, S. Margiotta, F. Mazzone, S. Negri, and C. Vassena, "Modelling hydrostratigraphy and groundwater flow of a fractured and karst aquifer in a Mediterranean basin (Salento peninsula, southeastern Italy)," Environmental Earth Sciences, vol. 67, no. 7, pp. 1891-1907, 2012.

[29] S. Margiotta and S. Negri, Alla Ricerca dell'Acqua Perduta, Congedo Editore, in Italian, 2004.

[30] M. Polemio, "Monitoring and management of karstic coastal groundwater in a changing environment (Southern Italy): a review of a regional experience," Water, vol. 8, no. 4, p. 148, 2016.

[31] V. Cotecchia, D. Grassi, and M. Polemio, "Carbonate aquifers in Apulia and seawater intrusion," Giornale di Geologia Applicata, vol. 1, pp. 219-231, 2005.

[32] G. De Filippis, M. Giudici, S. Margiotta, F. Mazzone, S. Negri, and C. Vassena, "Numerical modeling of the groundwater flow in the fractured and karst aquifer of the Salento peninsula (Southern Italy)," Acque Sotterranee-Italian Journal of Groundwater, vol. 2, no. 1, 2013.

[33] G. De Filippis, M. Giudici, S. Margiotta, and S. Negri, "Conceptualization and characterization of a coastal multilayered aquifer system in the Taranto Gulf (southern Italy)," Environmental Earth Sciences, vol. 75, no. 8, 2016.

[34] G. De Filippis, L. Foglia, M. Giudici, S. Mehl, S. Margiotta, and S. L. Negri, "Seawater intrusion in karstic, coastal aquifers: current challenges and future scenarios in the Taranto area (southern Italy)," Science of the Total Environment, vol. 573, pp. 1340-1351, 2016.

[35] G. De Filippis, L. Foglia, M. Giudici, S. Mehl, S. Margiotta, and S. L. Negri, "Effects of different boundary conditions on the simulation of groundwater flow in a multi-layered coastal aquifer system (Taranto Gulf, southern Italy)," Hydrogeology Journal, vol. 25, no. 7, pp. 2123-2138, 2017.

[36] A. Romanazzi, F. Gentile, and M. Polemio, "Modelling and management of a Mediterranean karstic coastal aquifer under the effects of seawater intrusion and climate change," Environmental Earth Sciences, vol. 74, no. 1, pp. 115-128, 2015.

[37] T. Darwish, T. Atallah, M. El Moujabber, and N. Khatib, "Salinity evolution and crop response to secondary soil salinity in two agro-climatic zones in Lebanon," Agricultural Water Management, vol. 78, no. 1-2, pp. 152-164, 2005.

[38] S. Margiotta and S. Negri, "Geophysical and stratigraphical research into deep groundwater and intruding seawater in the Mediterranean area (the Salento Peninsula, Italy)," Natural Hazards and Earth System Science, vol. 5, no. 1, pp. 127136, 2005.

[39] D. Grassi, T. Tadolini, and L. Tulipano, Influenza delle Caratteristiche Morfologiche - Strutturali e Paleogeografiche sull'Idrogeologia della Zona Situata a Nord di Otranto (Penisola Salentina), III Conv. Int. sulle Acque Sott., Palermo, 1975.

[40] L. Zorzi and C. Reina, "Le acque sotterranee in terra d'Otranto," in Cassa per il Mezzogiorno, pp. 1-94, Arti Grafiche "G. Menaglia", Roma, 1955.

[41] A. W. Harbaugh, MODFLOW-2005, The U.S. Geological Survey Modular Ground-Water Model - The GroundWater Flow Process, U.S. Geological Survey, Techniques and Methods 6-A16, 2005.
[42] C. D. Langevin, D. T. J. Thorne, A. M. Dausman, M. C. Sukop, and W. Guo, SEAWAT Version 4: A Computer Program for Simulation of Multi-Species Solute and Heat Transport, U.S. Geological Survey Techniques and Methods 6-A22, 2007.

[43] G. De Filippis, I. Borsi, L. Foglia et al., "Software tools for sustainable water resources management: the GIS-integrated FREEWAT platform," Rendiconti Online della Società Geologica Italiana, vol. 42, pp. 59-61, 2017.

[44] R. Rossetto, I. Borsi, and L. Foglia, "FREEWAT: FREE and open source software tools for WATer resource management," Rendiconti Online della Società Geologica Italiana, vol. 35, pp. 252-255, 2015.

[45] R. Rossetto, G. De Filippis, I. Borsi et al., "Integrating free and open source tools and distributed modelling codes in GIS environment for data-based groundwater management," Environmental Modelling \& Software, vol. 107, pp. 210-230, 2018.

[46] M. Abusaada and M. Sauter, "Studying the flow dynamics of a karst aquifer system with an equivalent porous medium model," Groundwater, vol. 51, no. 4, pp. 641-650, 2013.

[47] Regione Puglia \& Autorità di Bacino della Puglia, Aggiornamento del Bilancio Idrogeologico dei Corpi Idrici Sotterranei della Regione Puglia; All.4.5: Caratteristiche della Circolazione Idrica negli Acquiferi Carbonatici Pugliesi: Deflussi a Mare e Scambi Idrici tra Idrostrutture Confinanti, 2010, in Italian.

[48] PROTEZIONE CIVILE PUGLIA, 2018, October 2018, http://www.protezionecivile.puglia.it.

[49] C. W. Thornthwaite, "An approach toward a rational classification of climate," Geographical Review, vol. 38, no. 1, pp. 55-94, 1948.

[50] R. G. Allen, L. S. Pereira, D. Raes, and M. Smith, FAO Irrigation and Drainage Paper No. 56, Food and Agriculture Organization of the United Nations 56, no. 97, Rome, 1998.

[51] W. Guo and C. D. Langevin, User's Guide to SEAWAT: A Computer Program for Simulation of Three-Dimensional Variable-Density Ground-Water Flow, U.S. Geological Survey, Tallahassee, FL, USA, 2002.

[52] R. A. Freeze and J. A. Cherry, Groundwater, Prentice Hall, Englewood Cliffs, NJ, USA, 1979.

[53] F. W. Schwartz and P. A. Domenico, Physical and Chemical Hydrogeology, John Wiley, 1990.

[54] L. Scesi and P. Gattinoni, La Circolazione Idrica negli Ammassi Rocciosi, CEA, 2007.

[55] B. R. Scanlon, R. E. Mace, M. E. Barrett, and B. Smith, "Can we simulate regional groundwater flow in a karst system using equivalent porous media models? Case study, Barton Springs Edwards aquifer, USA," Journal of Hydrology, vol. 276, no. 1-4, pp. 137-158, 2003.

[56] QGIS Development Team, QGIS Geographic Information System. Open Source Geospatial Foundation Project, 2009, http://qgis.osgeo.org.

[57] G. Ponzini and A. Lozej, "Identification of aquifer transmissivities: the comparison model method," Water Resources Research, vol. 18, no. 3, pp. 597-622, 1982.

[58] G. Ponzini and G. Crosta, "The comparison model method: a new arithmetic approach to the discrete inverse problem of groundwater hydrology, 1, one-dimensional flow," Transport in Porous Media, vol. 3, no. 4, pp. 415-436, 1988.

[59] G. Ponzini, G. Crosta, and M. Giudici, "Identification of thermal conductivities by temperature gradient profiles: one-dimensional steady flow," Geophysics, vol. 54, no. 5, pp. 643-653, 1989. 
[60] S. Scarascia and G. Ponzini, "An approximate solution for the inverse problem in hydraulics," L'Energia Elettrica, vol. 49, pp. 518-658, 1972.

[61] E. P. Poeter, M. C. Hill, D. Lu, C. R. Tiedeman, and S. Mehl, UCODE_2014, with New Capabilities to Define Parameters Unique to Predictions, Calculate Weights Using Simulated Values, Estimate Parameters with SVD, Evaluate Uncertainty with MCMC, and More, Integrated Groundwater Modeling Center Report Number GWMI 2014-02, 2014.

[62] M. C. Hill and C. R. Tiedeman, Effective Groundwater Model Calibration with Analysis of Data, Sensitivities, Predictions, and Uncertainty, Wiley \& Sons, New York, NY, USA, 2007.

[63] M. Fidelibus and A. Pulido-Bosch, "Groundwater temperature as an indicator of the vulnerability of karst coastal aquifers," Geosciences, vol. 9, no. 1, p. 23, 2019.

[64] Regione Puglia \& SOGESID SpA, Piano di Tutela delle Acque, 2009 , in Italian.

[65] G. C. Calò, R. Tinelli, D. Lucrezio, and M. Stani, "Riscontri delle oscillazioni eustatiche Flandriane nelle acque profonde degli acquiferi salentini (Puglia)," Giornale di Geologia Applicata, vol. 2, pp. 341-347, 2005.

[66] G. Aiello and F. Budillon, "Lowstand prograding wedges as fourth-order glacio-eustatic cycles in the Pleistocene continental shelf of Apulia (southern Italy)," in Cyclostratigraphy: Approaches and Case Histories SEPM (Society for Sedimentary Geology), No. 81 ISBN 1-56576-108-1, pp. 215-230, 2004.

[67] S. Margiotta and P. Sansò, "The geological heritage of Otranto-Leuca Coast (Salento, Italy)," Geoheritage, vol. 6, no. 4, pp. 305-316, 2014.

[68] G. Mastronuzzi and P. Sansò, "Coastal towers and historical sea level change along the Salento coast (southern Apulia, Italy)," Quaternary International, vol. 332, pp. 61-72, 2014.

[69] M. Primavera, O. Simone, G. Fiorentino, and M. Caldara, “The palaeoenvironmental study of the Alimini Piccolo lake enables a reconstruction of Holocene sea-level changes in southeast Italy," The Holocene, vol. 21, no. 4, pp. 553-563, 2011.

[70] M. Bakker, "Analytic solutions for interface flow in combined confined and semi-confined, coastal aquifers," Advances in Water Resources, vol. 29, no. 3, pp. 417-425, 2006.

[71] A. C. Knight, A. D. Werner, and L. K. Morgan, "The onshore influence of offshore fresh groundwater," Journal of Hydrology, vol. 561, pp. 724-736, 2018. 

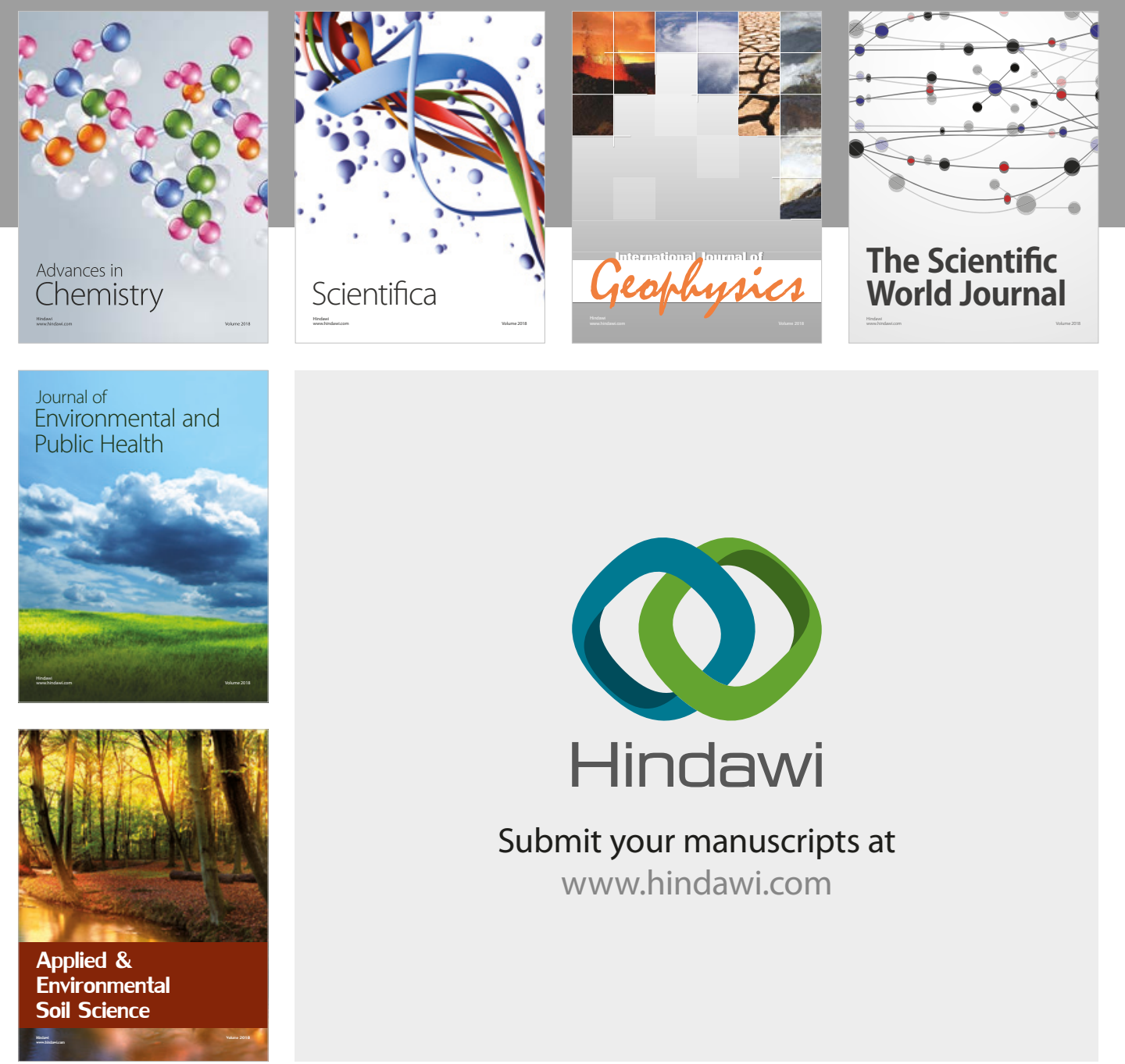

The Scientific

\section{World Journal}
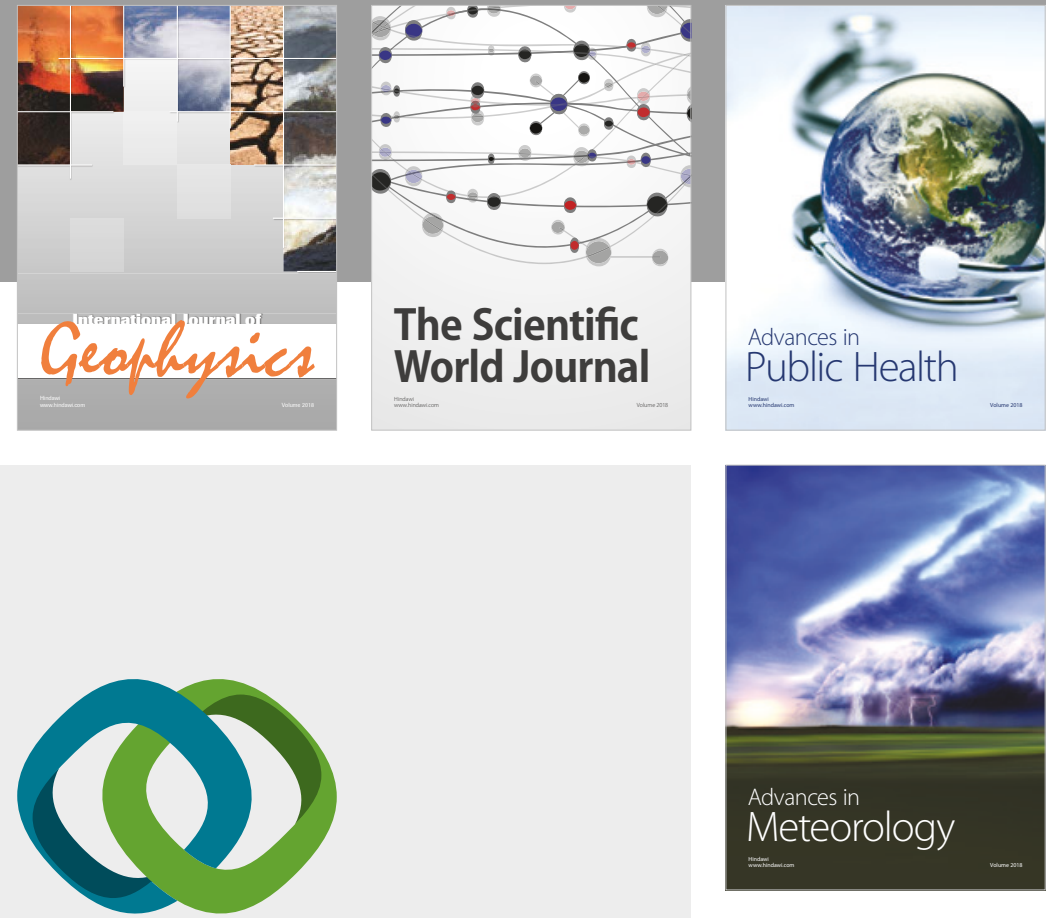

Advan

Public Health

\section{Hindawi}

Submit your manuscripts at

www.hindawi.com
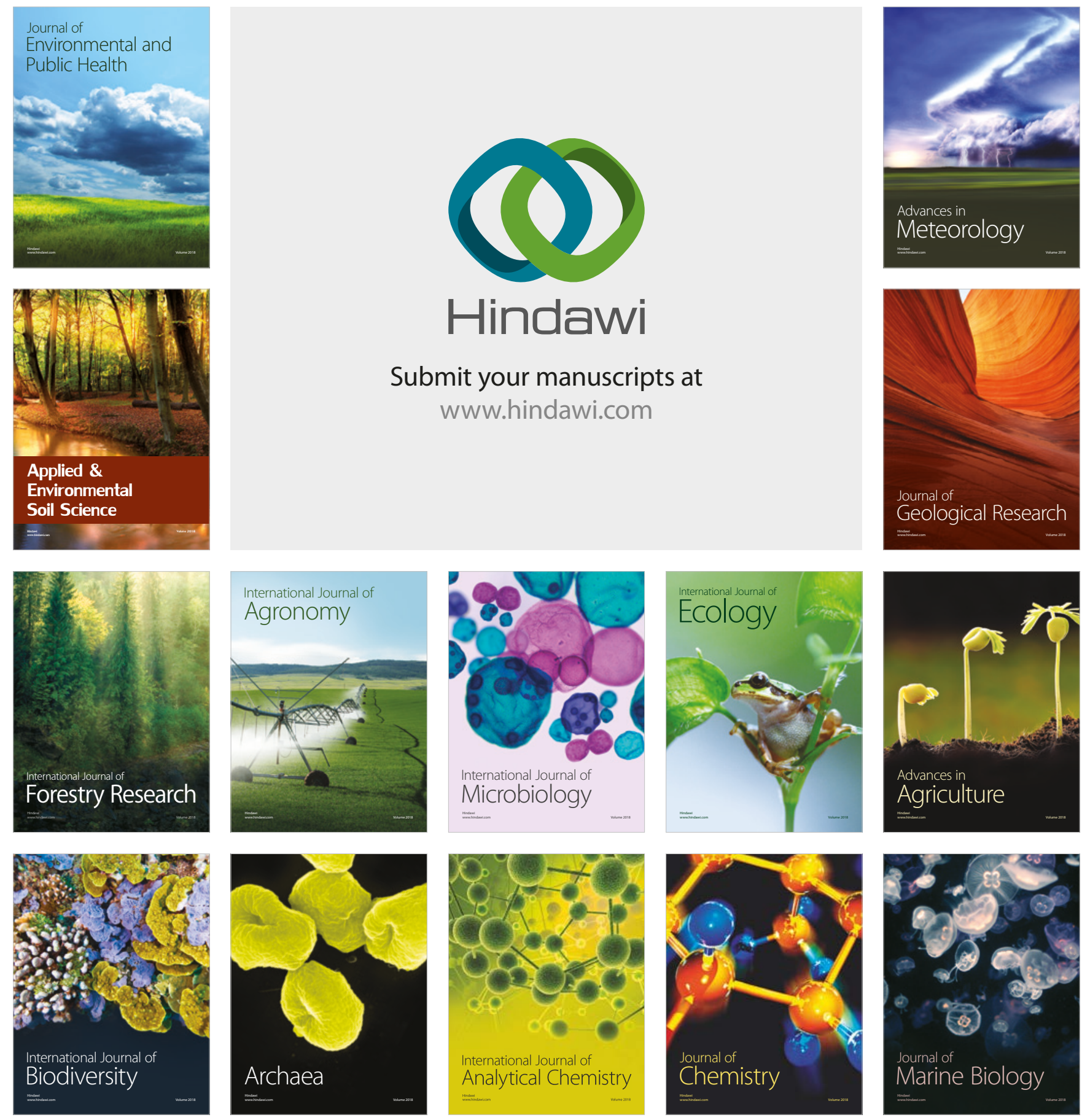